\title{
ESTUDO DA PREVALÊNCIA DA INFECÇÃO GENITAL POR PAPILOMAVÍRUS HUMANO EM AUXILIARES DE SERVIÇOS GERAIS NA FASE CLIMATÉRICA DA UNIVERSIDADE ESTADUAL DE MARINGÁ - PR
}

\section{LINDA EMIKO SUZUKI}

Tese de Doutorado apresentada ao Depar tamento de Saúde Matemo-Infantil da Faculdade de Saúde Pública da Universidade de São Paulo para obtenção do Grau de Doutor.

Área de concentração: Saúde MatemoInfantil

ORIENTADOR: PROF. DR. JOSÉ MENDES ALDRIGHI

São Paulo 2005

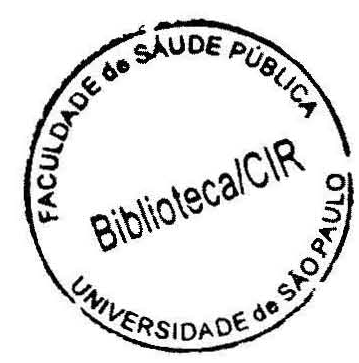


Autorizo, exclusivamente para fins acadêmicos e científicos, a reprodução total ou parcial desta tese, por processos fotocopiadores.

Assinatura: Seluzuki

Data: $18101 / 2005$

$45661 / 2005$ doe 
Hoje e sempre,

Fonte inspiradora de todo o bem,

DEUS

Aqueles que tanto amo,

Femando, Flávio, Humberto, Waldna

Marcos e Letícia 
A gratidão que não tem preço,

$A$ amizade que fica,

A lembrança,

Ao mestre Doutor Aldrighi 


\section{AGRADECIMENTOS}

Às mulheres que gentilmente participaram do estudo, àquelas que vencendo a timidez participaram, àquelas que por vergonha recuaram, para todas enfim, a minha oração.

Ao Dr. Ismael Santos Guerreiro que tão gentilmente me acolheu em seu laboratório.

Aos Dr. Sérgio Nicolau, Dr Israel Nunes Alecrin e Dra Cecília Roteli Martins pelas contribuições inestimáveis.

Ao casal amigo Dra Taqueco Uchimura e Dr Nelson Uchimura, muito a agradecer.

À Universidade Estadual de Maringá que me concedeu mais essa oportunidade de crescimento.

À Faculdade de Saúde Pública da Universidade de São Paulo com a equipe do Departamento de Saúde Matemo-Infantil que me fez sentir em casa, especialmente, lara, Leandro e Mary.

Àqueles cujos nomes ou semblantes ficaram gravados em meu coração nessa empreitada, a minha gratidão. 


\section{ÍNDICE}

1 INTRODUÇÃO

1.1 Epidemiológia do HPV 5

1.2 Taxonomia e Organizaçåo Genômica 6

1.3 Potencial Oncogênico 8

1.4 Transmissão e Fatores de Risco 9

1.5 Diagnóstico do HPV 11

2 OBJETIVO 14

3 CASUISTICA 15

4 MÉTODOS 17

4.1 Protocolo de Estudo 17

4.2 Variáveis Demográficas $\quad 18$

4.3 Variáveis Clínicas e Epidemiológicas 19

4.4 Citologia Oncológica Cérvico-Vaginal (CO) 20

4.5 Reação em Cadeia da Polimerase (PCR) 21

5 RESULTADOS 23

5.1 Variáveis Demográficas 23

5.2 Variáveis Clínicas e Epidemiológicas 26

5.3 Exames de Citologia Oncológica Cérvico-Vaginal (CO) 29

5.4 Reação em Cadeia da Polimerase (PCR) 32

6 DISCUSSÃO

7 CONCLUSÃO $\quad 48$ 


\section{ANEXOS}

Anexo 1 - Parecer do Comitê de Ética em Pesquisa da

Faculdade de Saúde Pública da Universidade de São

Paulo

Anexo 2 - Parecer do Comitê Permanente de Ética em

Pesquisa Envolvendo Seres Humanos da Universidade

Estadual de Maringá

Anexo 3 - Termo de Consentimento Livre e Esclarecido

A3

Anexo 4 - Questionário da Entrevista

A4

Anexo 5 - Procedimento para Colheita Tríplice do Material

Cérvico - Vaginal

Anexo 6 - Laudo de Colpocitologia

A14 


\section{LISTA DE TABELAS E FIGURAS}

Tabela 1 - Distribuição do número e percentual de mulheres segundo as variáveis demográficas.

Maringá-PR, 2003.

Tabela 2 - Distribuição do número e percentual de mulheres segundo a idade e o comportamento sexual. Maringá - PR, 2003.

Tabela 3 - Distribuição do número e percentual de mulheres segundo as variáveis clínicas e epidemiológicas. Maringá - PR, 2003.

Figura 1 - Distribuição percentual dos exames de Papanicolaou de acordo com sua classificação. Maringá-Pr, 2003 .

Figura 2 - Distribuição percentual dos exames de citologia oncológica de acordo com o tipo de esfregaço. Maringá-PR, 2003.

Figura 3 - Distribuição percentual dos exames de citologia oncológica de acordo com o tipo de flora vaginal. Maringá-PR, 2003.

Figura 4 - Distribuição percentual dos exames de citologia oncológica de acordo com os processos benignos. Maringá-PR, 2003.

Figura 5 - Distribuição percentual dos exames de citologia oncológica de acordo com o trofismo citológico. Maringá-PR, 2003. 


\section{RESUMO}

Suzuki LE. Estudo da prevalência da infecção genital por Papilomavirus humano em auxillares de serviços gerais na fase climatérica da Universidade Estadual de Maringá São Paulo; 2005. [Tese de Doutorado Faculdade de Saúde Pública da USP].

Objetivo. Sabe-se que a infecção genital por Papilomavirus humano (HPV), doença sexualmente transmissivel, é o principal fator na etiologia do câncer cérvico-uterino. O Ministério da Saúde do Brasil tem se empenhado na detecção de lesões precursoras da doença, porque um pico de incidência pode ocorrer em mulheres de 40 a 60 anos; no entanto, a incidência de HPV na mulher no climatério não é bem conhecida. Verificou-se a freqüência de HPV em serventes de 40 a 60 anos, da Universidade Estadual de Maringá. Métodos. Oitenta e oito mulheres responderam ao questionário sócio-demográfico e comportamental, 73 realizaram a pesquisa de DNA do HPV por reação em cadeia da polimerase (PCR) e 76 a colpocitologia oncológica. Resultados. A idade média foi de 48,8 anos $\left(D P_{ \pm 5}, 7\right)$; a menarca ocorreu em média aos 13,5 anos $(D P \pm 2,0)$ e $45,5 \%$ com menarca tardia; sendo que $47,7 \%$ tiveram a primeira relação com mais de 20 anos; a média foi de 20,9 anos $(D P \pm 5,1)$. A idade média da menopausa foi de 46,4 anos (DP $\pm 5,0$ ) e $61,4 \%$ estavam no menacme. Nos últimos 3 anos $77,3 \%$ tiveram um parceiro. Todas haviam realizado o preventivo de câncer ginecológico anual. A colpocitologia resultou em $59,2 \%$ normais e $40,8 \%$ inflamatórias. Foram encontrados Mobiluncus $s p$, Gardnerela vaginalis, fungos. Nenhum caso sugestivo de HPV foi detectado pela colpocitlogia, e, nenhum DNA de HPV foi encontrado por PCR. Conclusão. A freqüência de Papilomavírus em mulheres de 40 a 60 anos cuja colpocitologia apresentaram-se normais e inflamatórios, sem atipias citológicas, foi zero.

Descritores: Papilomavírus humano. Climatério. Epidemiologia. 


\section{SUMMARY}

Suzuki LE. Estudo da prevalêncla da infeç̧ão genital por Papilomavirus humano em auxillares de serviços gerais na fase climatérica da Universidade Estadual de Maringá São Paulo (BR); 2005. [Tese de Doutorado - Faculdade de Saúde Pública da USPI.

Objetive. It is known that human Papilomavirus (HPV), disease sexually transmissible, it is the principal factor to associated to the aetiology of the cérvico-uterine cancer. The Ministério da Saúde do Brasil has determined in the detection of precursory lesions of the disease, because a pick can happen in age group from 40 to 60 years; however, the incidence of HPV in the climacteric woman is not very known. The frequency of HPV was verified in servants from 40 to 60 years in Universidade Estadual de Maringá. Methods. It was studied 88 women that answered to the demographic and comportamental questionnaire, 73 accomplished the research of DNA HPV for chain reaction of the polimerase and 76 the Pap test. Results. The medium age was of 48,8 years $(D P \pm 5,7)$; the menarca happened on average to 13,5 years $(D P \pm 2,0)$ with $45,5 \%$ with late menarca and $47,7 \%$ had the first relationship with more than 20 years, and the average was 20,9 years $(D P \pm 5,1)$. The menopause's medium age was 46,4 years (DP $\pm 5,0$ ) and $61,4 \%$ were in the menacme. In the last 3 years $77,3 \%$ had just a partner. All had accomplished the preventive of gynecological cancer. The Pap test resulted in 59,2\% normal and $40,8 \%$ inflammatory. They were found Mobiluncus sp, Gardnerela vaginalis, Candida $s p$. No suggestive case of HPV was detected. DNA of HPV was not found. Conclusion. The frequency of HPV in women in the 40 to 60 years wich Pap test normal or just inflammatory without cytological atipias, it was zero.

Descriptors: Human papillomavirus. Climateric. Epidemiology. 


\section{INTRODUÇÂO}

O envelhecimento populacional vem sendo observado em todo o planeta. Segundo GARCIA e cols. (2002), as projeções da Organização Mundial da Saúde para 2025, incluem o Brasil entre os dez países do mundo com maior contingente de pessoas com 60 anos ou mais. A proporção de idosos no Brasil passou de 6,3\% em 1980 para 7,6\% em 1996, estimando-se em 14\% para 2025. Esta mudança demográfica corresponde uma transição epidemiológica que resulta em um importante crescimento da demanda aos serviços sociais e de saúde (GARCIA e cols. 2002; PAES 2004).

A expectativa de vida da mulher brasileira, conforme a Organização Mundial da Saúde, é de 65,7 anos e o gasto em saúde, por pessoa, foi de U\$ 573 em 2001 (WORLD HEALTH ORGANIZATION 2004). Como as mulheres vivem mais e são mais numerosas, há que avaliar os programas de saúde da mulher sob a ótica da população que envelhece, porque segundo PAES (2004) em seu estudo referente ao período de 1980 a 1995, as açōes e atençōes à saúde adotadas no Brasil, não resultou em modificação nos niveis de mortalidade por doenças infecciosas e parasitárias naquele período.

O climatério é definido como o período de vida da mulher compreendido entre os 40 e 65 anos de idade e caracterizado pela diminuição progressiva dos níveis séricos de estrogênio e progesterona e aumento do hormônio folículoestimulante $(\mathrm{FSH})$ conseqüente à diminuição dos folículos ovarianos (WORLD 
HEALTH ORGANIZATION 1996, OLIVEIRA e LEMGRUBER 2001; PINOTTI e BARROS 2004). Por outro lado, a menopausa é um episódio dentro do climatério que se refere à última menstruação, próximo aos 50 anos de idade (WORLD HEALTH ORGANIZATION 1996). No Brasil, segundo PINOTTI e BARROS (2004) a menopausa ocorre em média aos 47,8 anos.

ROBERTO NETTO (2001) relatou com dados da Organização Mundial de Saúde que a partir de 2020 serão diagnosticados 1 milhão de novos casos de câncer por ano. Cerca de 70 \% deles ocorrerão em países em desenvolvimento e apenas $5 \%$ desses paises possuem recursos para o controle da doença. Se medidas de prevenção e controles não forem tomadas, dentro de 20 anos, a incidência de câncer aumentará em aproximadamente $100 \%$. Sabe-se que, utilizando apenas os conhecimentos científicos e tecnologias existentes, poder-se-ia reduzir em um quarto de todos os cânceres e curar-se-ia uma terça parte. O que se tem certeza é que estratégias preventivas poderiam, com baixo custo, reduzir substancialmente a incidência de câncer principalmente o do colo uterino (MINISTÉRIO DA SAÚDE 2004).

No Brasil, estima-se que o câncer do colo do útero seja o terceiro mais comum na população feminina, sendo superado pelo câncer de pele não melanoma e de mama. Este tipo de câncer representa $10 \%$ de todos os tumores malignos em mulheres. É uma doença que pode ser prevenida, estando diretamente vinculada ao grau de subdesenvolvimento do país (MINISTÉRIO DA SAÚDE 2005). O câncer de colo do útero foi responsável pela morte de 5.800 mulheres no Brasil em 2000. Apesar do conhecimento cada vez 
maior nesta área, a abordagem mais efetiva para o controle do cáncer do colo do útero continua sendo o rastreamento através do exame de Papanicolaou (citologia oncológica cérvico-vaginal). É fundamental que os serviços de saúde orientem sobre a importância do exame preventivo, pois a realização periódica permite reduzir em $70,0 \%$, a mortalidade por câncer do colo do útero na população de risco (MINISTÉRIO DA SAÚDE 2004; AMERICAN CANCER SOCIETY 2005).

Em 1998, o MINISTÉRIO DA SAÚDE, lançou o programa Nacional de Combate ao Câncer de Colo de útero (Programa Viva Mulher), utilizando o exame citológico anual de Papanicolaou do esfregaço cérvico-vaginal como método de rastreamento da doença em mulheres de 25 a 60 anos e naquelas que tinham atividade sexual independente da idade. Na fase inicial, priorizou mulheres com idade entre 35 a 49 anos e aquelas que nunca haviam se submetido ao exame (MINISTÉRIO da SAÚDE 2004).

O que se sugere hoje é que toda mulher que tem ou já teve atividade sexual deva submeter-se ao exame periódico, especialmente aquelas de 25 a 59 anos de idade. Inicialmente o exame deve ser feito a cada ano. Se dois exames anuais seguidos apresentarem resultados negativos para displasia ou neoplasia, o exame pode passar a ser feito a cada três anos (MINISTÉRIO DA SAÚDE 2004). Segundo a Organização Mundial da Saúde (WORLD HEALTH ORGANIZATION 1996) em mulheres entre 35 - 64 anos, após um exame negativo, o exame subseqüente pode ser a cada três anos, com a mesma eficácia anual. Sendo que a redução ao risco seria de $93 \%$ se fizesse exame 
anual e de $91 \%$ se fosse realizado a cada três anos. O efeito protetor a cada cinco anos do exame preventivo seria de $84 \%$ e de $4 \%$ a cada 10 anos (GOLDIE e cols. 2004; WORLD HEALTH ORGANIZATION 2004).

No estado do Paraná, em 2003, ocorreram 176 mortes por câncer de colo de útero, a estimativa era de 310 óbitos. Pode-se dizer que o Programa Viva Mulher, vinculado ao Ministério da Saúde, tem mostrado bons resultados na redução de mortes por esta doença no estado do Paraná (SECRETARIA DA SAÚDE DO ESTADO DO PARANÁ 2004). Apesar do sucesso do programa, essas mortes seriam evitáveis por diagnóstico precoce, na sua fase inicial,

Vários são os fatores de risco identificados para o câncer do colo do útero. Os fatores sociais, ambientais e os hábitos de vida, tais como, atividade sexual antes dos 18 anos de idade, pluralidade de parceiros sexuais, vício de fumar (diretamente relacionado à quantidade de cigarros fumados), inadequados hábitos de higiene e o uso prolongado de contraceptivos orais parecem estar relacionados ao desenvolvimento de câncer de colo uterino (SCHIFFMAN e CASTLE 2003; MINISTÉRIO DA SAÚDE 2004).

Estudos feitos por SMITH e cols. (2002), mostraram ainda que, o Papilomavirus humano (HPV) e Chlamydia têm papel importante no desenvolvimento da displasia das células cervicais e na sua transformação em células cancerosas. O vírus do Papiloma humano está presente em 95 a $99 \%$ dos casos de câncer do colo do útero (GROSS e BARRASSO 1999; NAUD e cols. 2000; SECRETARIA DA SAÚDE DO ESTADO DO PARANÁ 2004). Em mulheres infectadas pelo Papilomavírus, há outros fatores de risco importantes 
imbricados no desenvolvimento do câncer. número elevado de gestaçð̃es, o uso de contraceptivos orais, tabagismo, infecção pelo HIV e outras doenças sexualmente transmitidas como herpes e clamidia (KOSKELA 2000).

A infecção genital pelo Papilomavírus humano é considerada doença sexualmente transmissivel (DST) muito comum. Por ser altamente transmissivel e ter prevalência alta, é um importante problema em saúde pública.

\subsection{Epidemiologia do HPV}

As informações epidemiológicas sobre as infeç̧ões por Papilomavirus humano (HPV) são muito variadas porque muitas infecções são sub-clínicas. Esse vírus não cresce em meios de cultura, assim, o diagnóstico preciso é feito pela pesquisa do DNA ou o RNA viral (BORGES e cols. 2004). Aliado ao fato de que as doenças sexualmente transmissiveis não são de notificação obrigatória existe uma dificuldade real quando se trata da prevalência da doença no Brasil.

NAUD e cols. (2000) referiram sendo a prevalência do HPV crescente no Brasil, sendo uma das queixas freqüentes na prática ginecológica e de outras especialidades como dermatologia, urologia e proctologia.

Apesar de dificuldades diagnósticas e de notificaçāo, as lesōes genitais visíveis aparecem em $1,0 \%$ dos adultos sexualmente ativos e $15,0 \%$ pela identificação do DNA do vírus HPV (KOUTSKY 1997; JOSEFSSON e cols. 2000). NAUD e cols. (2000) por outro lado, apresentam uma prevalência de 20 
a $65 \%$ salientando que esse virus se encontra em significante estado emergente.

Baseado na literatura existente a prevalência do HPV varia dependendo da população, do método utilizado para a sua detecção bem como da faixa etária estudada (DILLNER e cols. 2000; SMITH e cols. 2004).

\subsection{Taxonomia e Organização genômica}

O HPV pertence a família Papovavinidae e caracteriza-se por possuir capsídeos icosaédricos (sem envelope lipoprotéico) e única molécula de DNA circular, dupla, sendo sua massa molecular de 3 a $5 \times 10$ daltons e por serem positivos à reação de polimerase; e, tem sido detectado em grande número de vertebrados, porém, é muito específico para cada espécie e raramente ultrapassa a barreira da espécie (GROSS e BARRASSO 1999).

O HPV é altamente especifico para o homem por apresentar capsídeos mais largos, com diâmetro de $55 \mathrm{~nm}$ e seus cromossomos serem mais longos com 7.900 pares de bases nitrogenadas (GROSS e BARRASSO 1999):

O HPV pode ser classificado de acordo com a organização das seqüências de nucleotídeos do DNA, assim, os tipos de HPV representam os genótipos, os quais são denominados por números cardinais. Um tipo de HPV possui similaridade em $98 \%$ de seus nucleotideos. Até o momento, mais de 120 tipos de HPV foram descritos. O HPV pode ainda ser classificado conforme a especificidade do tecido infectado. Assim, esse virus pode ser cutaneotrópico, 
acometendo tanto os indivíduos imunocompetentes como os imunodeprimidos afetando áreas não genitais. Os tipos de HPV 1 a 4 e 10 e estão geralmente associados a lesర̃es verucosas (GROSS e BARRASSO 1999).

O vírus mucoso-genitotrópico que infecta especialmente a mucosa da genitália, pode ser encontrado em qualquer mucosa do organismo (oral; ocular ou respiratória). Sabe-se que em torno de 45 tipos do Papilomavírus humano infectam o trato genital. O HPV mucoso-genitotrópico pode ainda ser classificado de acordo com a sua transformação neoplásica em HPV de baixo risco e de alto risco. Os HPV tipo 6,11,42,43,44 ditos de baixo risco estão relacionados principalmente à verrugas genitais e neoplasias intra-epiteliais de baixo grau (LSIL). Os HPV de alto risco (tipo $16,18,26,31,33,35,39,45,51,52,53$, $56,58,59,66,73$ e 82 ) estão freqüentemente associados a neoplasias intraepiteliais de alto grau (HSIL) e neoplasias malignas do colo uterino (MUNOZ 2000; ROLON e cols. 2000).

A organização genômica de todos os HPV é semelhante. O genoma viral geralmente com nove a dez genes, pode ser dividido em três regiões: região precoce (early) com sete a oito genes, contém estruturas protéicas necessárias à replicação do DNA viral e possui propriedades de transformação oncogênica. A região tardia (late) constituída de dois genes com código para a formaçăo de proteínas do capsídeo viral; e, a regulatória ou de controle longo que contém a 
origem da replicação e o controle dos elementos para a transcrição e replicação (TUREK e cols. 1996).

Uma vez dentro da célula do hospedeiro o DNA viral pode assumir duas formas: a epissomal e a integrada. Na forma epissomal o DNA do vírus se encontra dentro do núcleo da célula do hospedeiro, porém, nåo se encontra ligado ao DNA do mesmo. A partir do momento em que o DNA viral se liga ao genoma da célula hospedeira, diz-se que está na forma integrada. A forma epissomal é encontrada nas vemugas genitais e lesōes de menor gravidade. Nas lesőes de maior gravidade como nos carcinomas in situ e invasivo, o DNA viral se encontra integrado ao DNA do hospedeiro (GROSS e BARRASSO 1999).

\subsection{Potencial Oncogênico}

Ao longo das últimas décadas a infecção pelo HPV tem se tomado importante em oncologia uma vez que alguns tipos de HPV interagem com fatores virais, ambientais, imunológicos e genéticos no processo de carcinogênese do câncer de colo de útero (SCHIFFMAN e CASTLE 2003).

No trato genital feminino o DNA do HPV é encontrado em 40,0 a 70,0\% das lesões intracervicais (NIC). Apesar de 95,0\% das neoplasias invasoras do colo uterino apresentar o DNA do HPV, apenas $1,0 \%$ das mulheres infectadas por um dos vários tipos oncogênicos, apresentam o risco para desenvolver o câncer (JOSEFSSON e cols. 2000). Há que se considerar também que as 
lesões de NIC podem regredir, permanecer inalteradas ou progredir para câncer cervical (DE BRUX e cols. 1983; HOLOWATY e cols. 1999; GOLDIE e cols. 2004).

Apesar das evidências mostrarem uma forte relação de causa e efeito entre HPV e câncer cérvico-vaginal, sabe-se que o vírus pode ser encontrado no trato genital inferior na forma latente por muitos anos ou, em alguns casos, ser responsabilizado pelo desenvolvimento de lesões de alto grau de malignidade. Essa interação tem como mediador o sistema imunológico, e a evolução das lesões intraepiteliais vai depender, entre outras variáveis, do estado geral em que se encontra o hospedeiro, do tipo de HPV, da carga viral (corresponde a número de partículas virais $/ \mathrm{mm}^{3}$ ) e da persistência da infecção (VILLA 1995; GONÇALVES 1998; CARVALHO e OYAKAWA 2000).

\subsection{Transmissão e Fatores de Risco}

Dependendo do tipo de HPV e das lesões clínicas associadas a ele, os HPV são transmitidos por contato direto da pele infectada, via sexual ou perinatal.

A transmissão sexual representa a via clássica de contaminação. A transmissão perinatal pode ocorrer durante o parto, porém é pequena e parece não estar relacionada ao tipo de parto (SEQUEIRA 2002); pode ainda ser no anteparto, tendo sido encontrado HPV no tecido placentário por EPPEL e cols. (2000). A transmissão pode ser por via transplacentária na infecção intra-uterina 
e ainda durante o parto pelo contato entre o feto e o trato genital matemo. (WANG e cols. 1998; TENTI e cols. 1999).

Os períodos de incubação para o condiloma acuminado causado pelo HPV 6 e 11 variam de 3 semanas a 8 meses (geralmente 4 a 12 semanas) e aqueles para verrugas cutâneas de 2 semanas a mais de 1 ano (CARVALHO e OYAKAWA 2000).

Na mulher os fatores de risco para o HPV se confundem com os de câncer no colo uterino. Ao longo das últimas décadas, estudos epidemiológicos têm apontado consistentemente a influência de alguns indicadores de atividade sexual no risco de infecção pelo HPV. É citado especialmente o número de parceiros sexuais, o comportamento sexual do(s) parceiro(s) (BRINTON e cols. 1987; BRINTON e cols 1989 a; BRINTON e cols. 1989 b) além da idade precoce do primeiro coito (VILLA 1995). O uso de contraceptivos orais, excluindo-se a progesterona injetável, a imunossupressão e o fumo também é citado (THOMAS e cols. 2001).

O tabagismo interfere diretamente na imunidade celular diminuindo a quantidade e a função das células de Langerhans, células apresentadoras de antígenos responsáveis pela ativação da imunidade celular no local da infecção (BARTON e cols. 1988; PINTO e cols. 2002).

Os fatores que levam à supressão ou perda da imunidade celular, como o uso de drogas citotóxicas em transplantados, imunodeficiências inatas ou adquiridas como em HIV aumentam a capacidade do vírus persistir no individuo (De SANJOS e PALEFSKY 2002). Apesar de ainda não ser bem estabelecida, 
durante a gravidez a freqüência de HPV parece ser maior que na população em geral (EPPEL e cols. 2000). A existência de HPV na gravidez expöe ao risco de transmissão fetal e ao recém-nato. E ainda, outros fatores de risco, como as DST prévias seja, herpes, clamídia, baixa ingestão de vitamina C e E têm sido sugerido (SCHIFFMAN e CASTLE 2003).

Como as demais DST, a incidência de HPV é maior nos primeiros anos de atividade sexual, ou seja, em jovens de 18 a 28 anos. Ocorrendo um declínio evidente de sua prevalência com a idade. Supõe-se que a transitoriedade da lesão, a provável redução da exposição a novos parceiros e o desenvolvimento de imunidade a alguns tipos de virus sejam a causa da diminuição da prevalência com a idade (SCHIFFMAN e CASTLE 2003).

\subsection{Diagnóstico do HPV}

O diagnóstico de HPV pode ser feito clinicamente ou com métodos laboratoriais de diagnóstico. A manifestação do HPV no trato genital inferior pode ser clínica, subclínica e latente. A forma clinica pode ser evidente ao exame clínico direto ou à simples inspeção. Já a forma subclínica é evidenciável apenas com o uso de colposcópio após aplicação de ácido acético, ou por citopatologia ou histopatologia. A forma latente é detectável somente pelas técnicas de biologia molecular (BORGES e cols. 2004). 
Os métodos diagnósticos para HPV diferem de acordo com a especialidade. Entre os métodos diagnósticos comumente utilizados em ginecologia, a citologia convencional, por ser de baixo custo, fácil, e rápida, é uma metodologia que pode ser utilizada para rastreamento de lesőes cervicais causadas pelo HPV. Existem ainda, os métodos de biologia molecular utilizado no diagnóstico de HPV tais como southem blot ou métodos de hibridização e o de amplificação do DNA ou a reação em cadeia da polimerase (PCR) (KOUTSKY 1997). A utilização da técnica da reação em cadeia da polimerase como metodologia de diagnóstico molecular do HPV tem se mostrado como a mais sensivel na identificação do material viral. Mas, pelo seu alto custo vem sendo usada predominantemente para estudos de pesquisa, impossibilitando a sua prática pública KANESHIMA e cols (2001). A metodologia é relativamente trabalhosa, no entanto, permite a detecção de um amplo leque dos tipos de HPV, ou seja, a caracterização do genotipo de HPV, mesmo quando somente pequeno número de cópias de DNA do vírus está presente, sendo assim, considerado padrão ouro (CHOW e cols. 2000). A colpocitologia oncológica convencional descrita por Papanicolaou sofreu algumas adaptaçōes ao longo do tempo. Entre as inovaçőes mais recentes está a citologia em base líquida, cujo exame traria maior acurácia principalmente em casos de lesões de significado indeterminado (ASCUS), por utilizar-se do raspado cérvico-vaginal em solução conservante líquida (AMERCAN CANCER SOCIETY 2005). Deste material se faria a colpocitologia e em casos de ASCUS e de interesse, se faria a pesquisa do DNA de HPV, chamada de teste reflexo. KIM e cols. (2002); 
SARODE e cols (2003) sugerem melhora na expectativa de vida e do custobenefício comparado a outras estratégias preventivas para as mulheres cujo diagnóstico citológico resultou em ASCUS. Porém, para rastreamento de câncer cérvico-uterino, além de necessitar de aparehagem própria, ser trabalhosa e de custo relativamente alto, comparado ao colpocitológico convencional, não tem sido usada em saúde pública.

Baseado na recomendação da Organização Mundial da Saúde o Ministério da Saúde do Brasil (MINISTÉRIO DA SAÜDE 2000) tem se empenhado na deteç̧ão de lesōes precursoras e de formas iniciais de câncer cérvico-uterino, pela colpocitologia oncológica, nas mulheres em fase do climatério porque um pico de incidência dessa doença pode ocorrer na faixa etária de 40 a 60 anos de idade. No entanto, a incidência de HPV na mulher na fase do climatério não é bem conhecida. Há que se considerar que a colpocitologia em mulheres peri e pós - menopausa encontra dificuldades técnicas tanto na obtenção de material cérvico-vaginal representativo como na detecção das alteraçōes citológicas provocadas pelo vírus. Estas dificuldades, aliado ao fato da literatura escassa, quanto à freqüência de HPV em mulheres na fase climatérica, foram motivos para estudar a prevalência do HPV nesse período da vida da mulher, respaldado pela técnica de biologia molecular. 


\section{OBJETIVO}

Estimar a prevalência da infecção genital por Papilomavirus humano em auxiliares de serviços gerais, na fase do climatério, com acesso a exames de rastreamento de câncer cervical, da Universidade Estadual de Maringá. 


\section{CASUística}

Para o estudo foram selecionados 101 mulheres, com mais de 40 anos de idade, auxiliares de serviços gerais da Universidade Estadual de Maringá (UEM-PR), em atividade no período entre 2003 e 2004.

Os critérios de inclusão no estudo foram: mulheres na fase do climatério; serventes em atividade na UEM, com útero intacto. Essa categoria foi escolhida por apresentarem freqüência relativa significativa de inflamação cérvico-vaginal, detectada por colpocitologia oncológica de exames preventivos anuais, anteriores.

Critérios de exclusão: mulheres com sangramento uterino anormal, as portadoras do vírus HIV, com mudança de função, aposentadas, em licença ou afastamento, com diagnóstico ou suspeita de câncer ginecológico, pacientes que foram tratadas por cirurgia radical para câncer de colo de útero e com incapacidade de assinar o Termo de Consentimento Livre e Esclarecido.

Os critérios de inclusão e exclusão foram confirmados pela história clinica, dados demográficos e exames laboratoriais de acordo com suas indicaçōes, fomecidos pelo Ambulatório Médico da Universidade Estadual de Maringá e resultado da entrevista.

O protocolo de estudo foi aprovado pela Comissão Científica e de Ética em Pesquisa da Faculdade de Saúde Pública da Universidade de São Paulo (FSP-USP) e pela Comissão Científica e de Ética em Pesquisa da 
Universidade Estadual de Maringá (UEM) (Anexos $1 \oplus 2$ ). Todas as mulheres participantes foram informadas sobre os procedimentos que seriam realizados e assinaram o Termo de Consentimento Livre e Esclarecido (Anexo 3).

Após a obtenção de informaç̋̃es sobre a condição trabalhista atual das servidoras, 13 mulheres foram excluidas por não se apresentarem em seu local de trabalho; eram elas: aposentadas, afastadas em licença ou por terem mudado de função e uma mulher por recusar a participar do estudo.

A casuistica final foi de 88 mulheres. 


\section{MÉTODOS}

O presente estudo foi do tipo transversal descritivo $e$ as características clínicas, epidemiológicas e demográficas foram reveladas pela aplicação de um questionário com as variáveis de interesse (Anexo 4).

\subsection{Protocolo de Estudo}

Todas as mulheres foram entrevistadas e responderam ao questionário constituido de 69 perguntas com questőes sócio-demográficas e comportamentais. $\mathrm{O}$ instrumento foi avaliado anteriormente em 15 pessoas selecionadas aleatoriamente (sorteio) de uma lista fomecida pelo setor de recursos humanos.

Essas mulheres foram submetidas aos exames de citologia oncológica cérvico-vaginal convencional (CO) e a pesquisa de DNA do Papilomavíns humano (HPV) pela reação em cadeia da polimerase (PCR). Sendo que, mulheres com quaisquer alterações detectadas que merecessem intervenções, foram encaminhadas ao Ambulatório Médico da Universidade Estadual de Maringá. 


\subsection{Variáveis Demográficas}

A idade das participantes foi conferida nos dados do Registro Geral (RG/identidade, obtida no setor de Recursos Humanos - UEM).

Em relação à raça, as mulheres foram classificadas como branca; mestiça (cruzamento de raças diferentes), negra e amarela, de acordo com a observação da pesquisadora.

A escolaridade das servidoras foi agrupada de acordo com o número de anos estudados em primário, primeiro, segundo e terceiro grau completo ou incompleto.

O rendimento per capita (rendimento total da familia dividido pelo número de pessoas por família) foi agrupado por categorias tendo como base o salário mínimo vigente na época da entrevista, ou seja, R\$240,00 e agrupados em:

< 1salário; 1 a 2 salários e $\geq 3$ salários.

Quanto à moradia verificou-se o número de dormitórios e o número de residentes por familia.

Em relação ao tempo de trabalho na UEM foram também listados $e$ agrupados em três categorias: $\leq 5$ anos; 6 a 10 anos e $>10$ anos de trabalho na UEM. 


\subsection{Variáveis Clínicas e Epidemiológicas}

De acordo com o número de partos as mulheres foram agrupadas em nuliparas (mulher que nunca pariu), primíparas (deu a luz a um filho), pauciparas ( 2 a 3 partos ) e multiparas ( $\geq 4$ partos).

Em relação as variáveis ginecológicas, as mulheres relataram a data da menarca em anos (primeira menstruaçåo da vida da mulher) e a data da ocorrência da menopausa (última menstruação de sua vida) sendo definida como natural, cirúrgica ou actínica, causada por radioterapia.

Investigou-se sobre a idade em que teve a primeira relação sexual, número de parceiros nos últimos 3 anos e o tempo de união com o mesmo parceiro.

Quanto ao uso de métodos contraceptivos (MC), verificou-se o uso de anticoncepcional oral (ACO); o uso de condom (camisinha) para o parceiro e laqueadura.

Sobre o uso da terapia hormonal da menopausa as mulheres foram inquiridas se tomaram ou não, o tipo de hormônio utilizado; se ainda estavam fazendo uso e por quanto tempo tomaram o medicamento. Considerou-se não usuária aquelas com suspensão do medicamento por mais de três meses.

Para o tabagismo, considerou-se o uso de tabaco em qualquer quantidade e grandes fumantes aquelas que fumavam 11 ou mais cigarros por dia (BURGER e cols. 1993). Essa informação foi obtida em entrevista, aquelas que tinham utilizado o tabaco havia mais de 12 meses foram consideradas ex- 
tabagistas (MENEZES e cols. 2002). As tabagistas foram agrupadas em três categorias de acordo com o número de cigarros fumados por dia: <10; 11 a 20 e $>20$ cigarros/dia.

Foram às mulheres, questionadas quanto a HPV como a neoplasia intraepitelial cervical (NIC).

Os resultados das variáveis foram expressos em freqüência relativa ou expressos como média \pm um desvio-padrão.

\subsection{Citologia Oncológica Cérvico-Vaginal (CO)}

Para a realização do exame de citologia oncológica cérvico-vaginal foram utilizadas amostras coletadas por técnica padrão VCE (Vaginal-CervicalEndocervical), segundo WIED (1955) utilizadas para confecção de esfregaços cérvico-vaginais (Anexo 5). As participantes foram orientadas para a abstinência sexual por 24 horas antes do exame; para não utilizar medicamentos (cremes, supositórios) vaginais por 48 horas antes do exame; para não fazerem lavagens vaginais ou pélvicas; e estarem fora do periodo menstrual. Medidas essas no sentido de não prejudicar a análise.

O exame colpocitológico foi realizado no setor de Citologia Clínica do Laboratório de Ensino e Pesquisa da Universidade Estadual de Maringá. Os esfregaços cérvico-vaginais foram fixados em álcool etílico e corados pelo método de coloração de Papanicolaou, modificado segundo TAKAHASHI (1982). Por microscopia ótica, sem imersão, permite pela análise das células e 
do esfregaço, determinar os casos normais daqueles com alteraçōes citopáticas compativeis com suspeita de infecção por HPV e os demais processos inflamatórios. Detecta também os casos de lesões intraepiteliais escamosas e carcinomas. Eventualmente, foi utilizada a objetiva de imersão para determinar a flora microbiana. Foi considerada vaginose quando a flora microbiana consistia de Gardnerella vaginalis elou Mobiluncus sp. Foi classificado como vaginite quando o esfregaço apresentava critérios inflamatórios como abundantes leucócitos elou agente infeccioso no material vaginal, excluindo os da vaginose (GOMPEL e KOSS 1997).

O laudo (Anexo 6) foi emitido conforme análise citológica e microbiológica no esfregaço do material cérvico-vaginal por coloração de Papanicolaou. No presente estudo foi utilizado o Sistema Bethesda revisado em 1997 (KURMAN e SOLOMON 1997).

\subsection{Reação em Cadeia da Polimerase (PCR)}

Em uma mesma visita, na ocasião da coleta da $\mathrm{CO}$, amostras endocervicais em tampão T.E. (Tris- $\mathrm{HCl} 10 \mathrm{mM}$ pH 8.5; EDTA $1 \mathrm{mM}$ ), foram coletadas e estocadas a -20C para posterior pesquisa de DNA do HPV por reação em cadeia da polimerase. A pesquisa do DNA do vírus foi realizada no Laboratório Experimental de Ginecologia e Obstetricia da Universidade Federal de Såo Paulo.

A extração do DNA foi feita pela proteinase $\mathrm{K}$. 
Todos os procedimentos desta técnica foram realizados com os critérios necessários de assepsia e anti-sepsia para evitar contaminações.

As PCR foram realizadas conforme o descrito por BAUER e MANOS (1993). Foram utilizados os oligonucleotídeos iniciadores $\beta$ globina $\mathrm{GH} 20$ e PC04, que amplificam parte do gene da $\beta$ globina humana e produzem fragmentos de 268 pares de base, sendo que esse gene pode ser utilizado como controle interno da reação de amplificação. Para detectar o HPV foram utilizados os iniciadores MY09 e MY11, descritos por MANOS e cols (1989) que amplificam especificamente uma parte do gene $L 1$ com 450 pares de base. Esta é a região mais conservada do genoma dos diferentes tipos de HPV e é responsável pela codificação dos genes que expressam a sintese do capsídeo viral.

O sistema de amplificação foi realizado em tubos tipo Eppendorf, onde no termociclador marca MJ Research foi realizada a reação de amplificação conforme o programa HPVL1.

Pela facilidade técnica e disponibilidade, foi utilizado o gel de agarose para a visualização dos produtos de amplificação, e corado com brometo de etídeo e lido no computador.

O diagnóstico ou confirmação de que o genoma do HPV estaria integrado às células cérvico-vaginais seria feito pela genotipagem, desde que, conforme a literatura, os genótipos de alto risco estão integrados às células. 


\section{RESULTADOS}

\subsection{Variáveis Demográficas}

Das 88 mulheres do estudo, $72,7 \%$ eram da raça branca e todas as mulheres da raça mestiça eram resultados do cruzamento de branco com negro. Nenhuma delas era da raça amarela (Tabela 1).

Em relação à escolaridade, $53,4 \%$ tinham pelo menos o segundo grau e 4 mulheres $(4,5 \%)$ tinham curso superior das quais $1,1 \%$ completo e $3,4 \%$ incompleto.

A freqüencia de mulheres casadas foi de $65,9 \%$ e a média de tempo de união foi de 16,1 anos; enquanto a freqüência de solteiras foi igual a $5,7 \%$.

O pai era falecido em $71,6 \%$ e $54,2 \%$ das mães eram falecidas (Tabela1). Os motivos de falecimento do pai foram, principalmente, doenças do coração e pulmão com $27,4 \%$ e $14,5 \%$ respectivamente. Os motivos de falecimento da mãe foram doenças do coração e derrame com $27,0 \%$ e $14,5 \%$ respectivamente.

A média de pessoas por família morando na mesma casa e a média de dormitórios foi de $3,7(D P \pm 1,4)$ e $2,7(D P \pm 0,7)$, respectivamente.

Em relação ao tempo de serviço na instituição a freqüência foi de $29,5 \%$ e $20,5 \%$ para as mulheres que trabalhavam entre 21 a 25 anos e 6 a 10 anos, respectivamente. A renda média per capita por familia foi de $\mathrm{R} \$ 308,30$ (DPI 161,9 ), sendo que faixa de renda entre $R \$ 240,00$ a $R \$ 480,00$ (1 a 2 salários 
mínimos), correspondeu a $60,2 \%$ de freqüência (Tabela 1). A menor renda per capita foi de $R \$ 23,00$ e a maior de $R \$ 933,00$. A moda foi $R \$ 200,00$ e a mediana de $R \$ 260,00$. 
Tabela 1 - Distribuição do número e percentual de mulheres segundo as variáveis demográflcas. Maringá-PR, 2003.

\begin{tabular}{|c|c|c|c|}
\hline VARLAVEIS & & $\mathbf{N}(88)$ & $\%$ \\
\hline Raça & $\begin{array}{l}\text { branca } \\
\text { mestiça } \\
\text { negra } \\
\text { amarela }\end{array}$ & $\begin{array}{c}64 \\
19 \\
5 \\
0\end{array}$ & $\begin{array}{c}72,7 \\
21,6 \\
5,7 \\
0,0\end{array}$ \\
\hline Escolaridade & $\begin{array}{l}\text { primário } \\
1^{\circ} \mathrm{grau} \\
2^{\circ} \mathrm{grau} \\
\text { superior }\end{array}$ & $\begin{array}{r}12 \\
25 \\
47 \\
4\end{array}$ & $\begin{array}{r}13,7 \\
28,4 \\
53,4 \\
4,5\end{array}$ \\
\hline Estado civil (em anos) & $\begin{array}{l}\text { solteira } \\
\text { casada } \\
\text { separada } \\
\text { Viúva }\end{array}$ & $\begin{array}{r}5 \\
58 \\
12 \\
13\end{array}$ & $\begin{array}{r}5,7 \\
65,9 \\
13,6 \\
14,8\end{array}$ \\
\hline Pai & $\begin{array}{l}\text { vivo } \\
\text { falecido } \\
\text { adotivo }\end{array}$ & $\begin{array}{c}24 \\
62 \\
2\end{array}$ & $\begin{array}{l}27,2 \\
70,5 \\
2,3\end{array}$ \\
\hline Mãe & $\begin{array}{l}\text { viva } \\
\text { falecida } \\
\text { adotiva }\end{array}$ & $\begin{array}{c}46 \\
40 \\
2\end{array}$ & $\begin{array}{c}52,3 \\
45,4 \\
2,3\end{array}$ \\
\hline$N^{0}$ pessoas/ familia & $\begin{array}{l}1 \\
2-3 \\
4-5 \\
26\end{array}$ & $\begin{array}{r}3 \\
40 \\
35 \\
10\end{array}$ & $\begin{array}{r}3,4 \\
45,5 \\
39,8 \\
11,3\end{array}$ \\
\hline$N^{\circ}$ dormitórios & $\begin{array}{l}1 \\
2 \\
3 \\
4\end{array}$ & $\begin{array}{c}2 \\
31 \\
46 \\
9\end{array}$ & $\begin{array}{r}2,3 \\
35,2 \\
52,3 \\
10,2\end{array}$ \\
\hline Tempo de trabalho (anos) & $\begin{array}{l}\leq 5 \\
6-10 \\
\geq 11\end{array}$ & $\begin{array}{l}14 \\
18 \\
56\end{array}$ & $\begin{array}{l}15.9 \\
20,5 \\
63,6\end{array}$ \\
\hline $\begin{array}{l}\text { Renda familiar per capita } \\
\text { (salário mínimo)* }\end{array}$ & $\begin{array}{l}<1 \\
1 \text { a } 2 \\
\geq 3\end{array}$ & $\begin{array}{c}3 \\
53 \\
32\end{array}$ & $\begin{array}{r}3,4 \\
60,2 \\
36,4\end{array}$ \\
\hline
\end{tabular}

* 1 salário mínimo= R\$240,00. 


\subsection{Variáveis Clínicas e Epidemiológicas}

A média de idade das mulheres incluídas no estudo foi de 48,8 anos $(D P \pm 5,7)$. A média de idade para a ocorrência da menarca foi de $13,5(\mathrm{DP} \pm$ 2,0 ) e a $1^{\circ}$ relaçăo sexual ocorreu em média aos 20,9 anos $(D P \pm 5,1)$. Setenta e sete por centro das mulheres eram ativas sexualmente na data da entrevista $\theta$ $77,3 \%$ delas tinham apenas um parceiro sexual nos últimos 3 anos. Quanto ao tempo de convivio com um único parceiro a freqüência foi de $35,2 \%, 7,9 \%$, $3,4 \%, 53,5 \%$, com os parceiros sexuais até 5 anos de união, $6-10$ anos, $11-15$ anos $e>15$ anos de uniăo, respectivamente (Tabela 2).

Quanto ao uso de método contraceptivo $(M C)$ O ACO foi utilizado por 23 mulheres $(26,1 \%)$ e o uso da camisinha não foi referido.

As mulheres nulíparas corresponderam a uma freqüenncia de $8,0 \%$ e as que tinham de 2 a 3 filhos vivos foi de $64,7 \%$ (Tabela2). Em relação a filhos, $92,0 \%$ apresentaram filhos vivos e 5 mulheres relataram terem tido aborto.

A idade para ocorrência da menopausa foi em média aos 46,4 anos (DP $\pm 5,0$ ); e a freqüência para a menopausa natural foi de $40,9 \%$ e de $16,0 \%$, cinúrgica. Não houve nenhuma menopausa actínica. Quarenta e dois por cento se encontravam no menacme (fase fértil da mulher) (Tabela 3).

A THM (terapia hormonal da menopausa) foi utilizada por 8 mulheres, 0 correspondente a uma freqüẻncia de $3,4 \%$. 
O tratamento por cauterização do colo uterino foi realizado em $45 \%$ das mulheres 11 a 20 anos atrás; e, a histerectomia total abdominal (HTA) em 10 servidoras e HTA com ooforectomia em 2 das 88 mulheres do estudo.

Sete mulheres $(8,0 \%)$ relataram terem tido HPV no passado, porém, tanto a colpocitologia como a pesquisa de DNA do vírus foi negativa. Por outro lado, 42 mulheres $(47,7 \%)$ não sabiam ou não se referiram à infecção pelo HPV (Tabela 3).

Houve apenas um caso de neoplasia intraepitelial de alto grau (NIC III) no passado, relatada pela própria entrevistada, porém, alterações citológicas não foram visualizadas na CO realizada, e, nem o DNA do HPV foi encontrado.

O uso do tabaco foi relatado por $33(37,5 \%)$ mulheres e $55(62,5 \%)$ nunca haviam fumado. 0 número de cigarros fumados por dia foi de $\leq 10$ cigarros $(64,8 \%) ; 11$ a 20 cigarros $(29,3 \%)$ e $\geq 21$ cigarros $(5,9 \%)$. 
Tabela 2 - Distribuiçăo do número e percentual de mulheres segundo a idade e comportamento sexual. Maringá - PR, 2003.

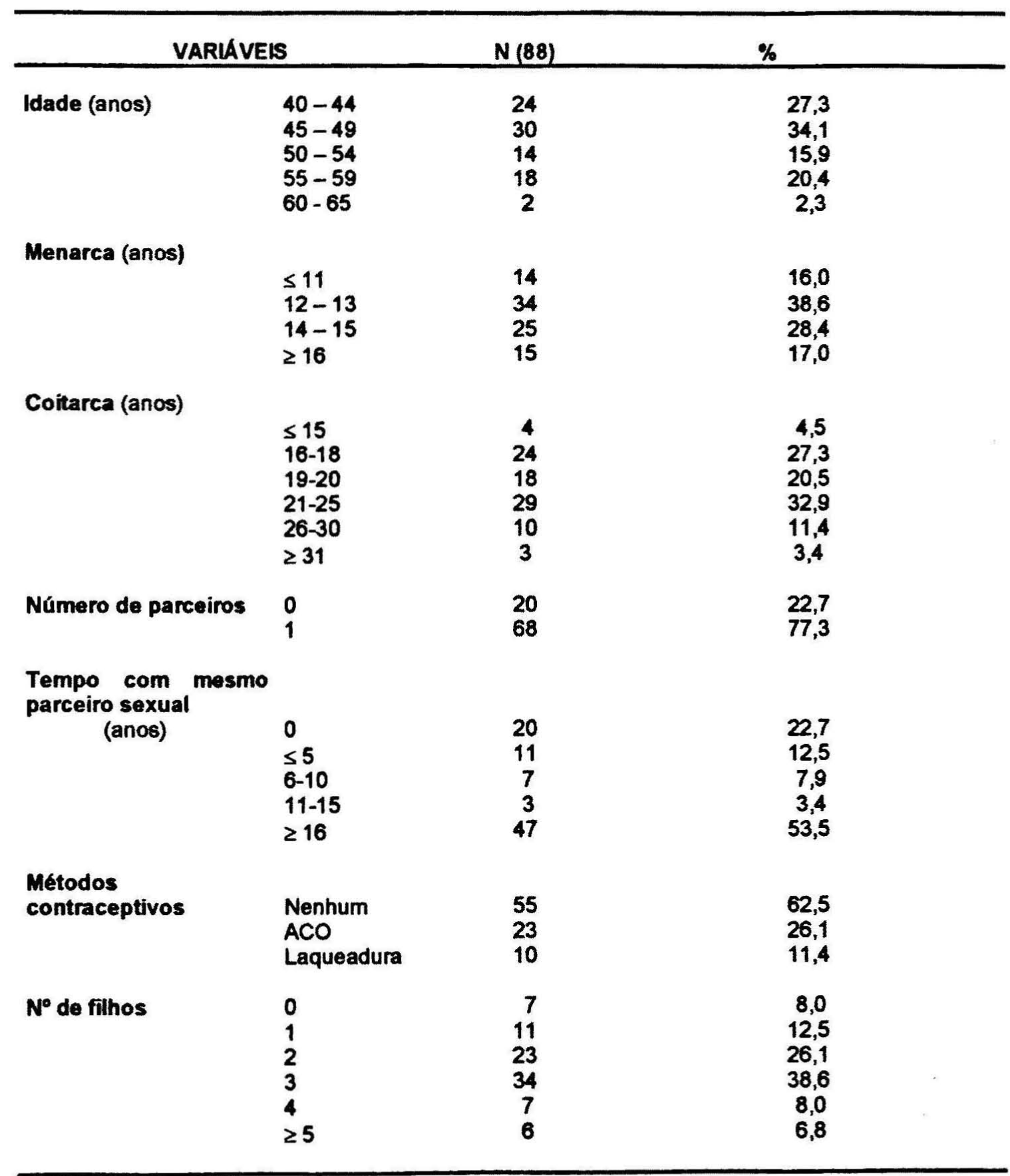


Tabela 3 - Distribuição do número e percentual de mulheres segundo as variáveis clínicas e epldemiológicas. Maringá - PR, 2003.

\begin{tabular}{|c|c|c|c|}
\hline \multicolumn{2}{|c|}{ VARIAVEIS } & \multirow{2}{*}{$\begin{array}{c}N(88) \\
38 \\
36 \\
14\end{array}$} & \multirow{2}{*}{$\begin{array}{l}\% \\
43,2 \\
40,9 \\
15,9\end{array}$} \\
\hline Tipo de menopausa & $\begin{array}{l}\text { Menacme } \\
\text { Natural } \\
\text { Cirúrgica }\end{array}$ & & \\
\hline Ondas de calor & $\begin{array}{l}\text { Sim } \\
\text { Não }\end{array}$ & $\begin{array}{l}48 \\
40\end{array}$ & $\begin{array}{l}54,5 \\
45,5\end{array}$ \\
\hline Antecedentes de HP & $\begin{array}{l}\text { Sim } \\
\text { Năo } \\
\text { Năo sabe } \\
\text { NIC III } \\
\text { Năo referiu }\end{array}$ & $\begin{array}{c}7 \\
38 \\
3 \\
1 \\
39\end{array}$ & $\begin{array}{l}8,0 \\
43,2 \\
3,4 \\
1,1 \\
44,3\end{array}$ \\
\hline Tabagismo & $\begin{array}{l}\text { Sim } \\
\text { Não }\end{array}$ & $\begin{array}{l}33 \\
55\end{array}$ & $\begin{array}{l}37,5 \\
62,5\end{array}$ \\
\hline $\begin{array}{l}\text { Tabagismo passivo } \\
\text { na infancia }\end{array}$ & $\begin{array}{l}\text { Sim } \\
\text { Não }\end{array}$ & $\begin{array}{l}69 \\
19\end{array}$ & $\begin{array}{l}78,4 \\
21,6\end{array}$ \\
\hline $\begin{array}{l}\text { Tabagismo passivo } \\
\text { idade adulta }\end{array}$ & $\begin{array}{l}\text { Sim } \\
\text { Não }\end{array}$ & $\begin{array}{l}45 \\
43\end{array}$ & $\begin{array}{l}51,1 \\
48,9\end{array}$ \\
\hline
\end{tabular}




\subsection{Exames de Citologia Oncológica Cérvico-Vaginal (CO)}

Foram realizados 76 exames de citologia oncológica cérvico-vaginal. Quarenta e cinco exames foram da classe I (59,2\%) e 31 exames classe II $(40,8 \%)$ conforme apresentados na Figura 1.

A freqüência de citologia normal foi de $59,0 \%$ e de exames inflamatórios ou infecciosos somaram 41,0\%, apresentados na Figura 2.

O resultado dos exames de $\mathrm{CO}$ apresentou uma freqüência de $57,0 \%$ para Lactobacilus. A flora não foi visualizada (flora nv) em 12,0\%. Flora mista, Gardnerella vaginalis, fungos e Mobiluncus sp, representaram $11,0 \%, 7,0 \%$, $4,0 \%$ e $1,0 \%$ respectivamente (Figura 3 ).

A freqüência dos processos benignos encontrados nos exames de $\mathrm{CO}$ foi de $49,0 \%, 24,0 \%$ e $3,0 \%$ para os exames sem alterações, com metaplasia escamosa e do tipo regenerativo, respectivamente, como na Figura 4.

Quanto ao trofismo citológico encontrado nos exames de $\mathrm{CO}$, apresentados na Figura 5, a freqüência foi de $59,0 \%, 16,0 \%, 11,0 \%, 9,0 \%$ e $5,0 \%$ para o normotrófico, atrófico, exame com avaliação prejudicada, hipotrófico e hipertrófico, respectivamente. 


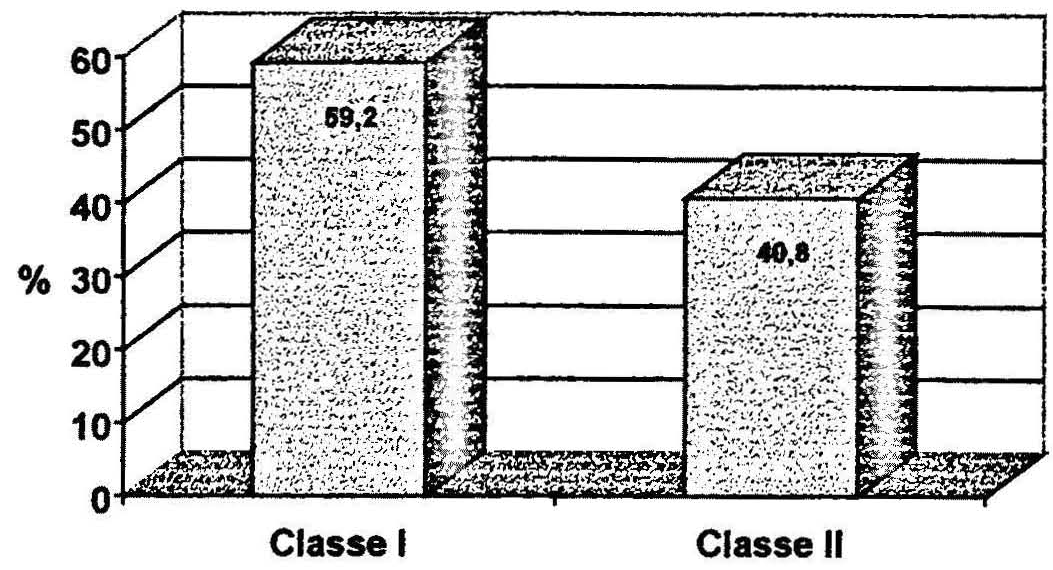

Figura 1 - Distribuição percentual dos exames de Papanicolaou de acordo com sua classificação. Maringá-Pr, 2003.

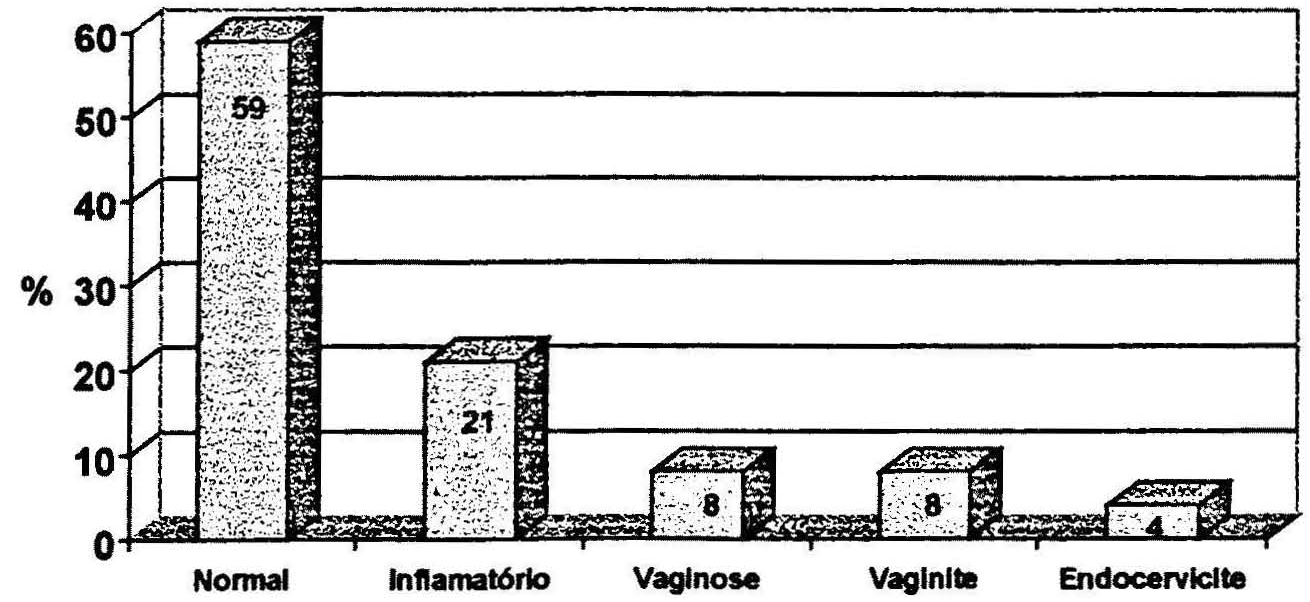

Figura 2 - Distribuição percentual dos exames de citologia oncológica de acordo com o tipo de esfregaço. Maringá-PR, 2003. 


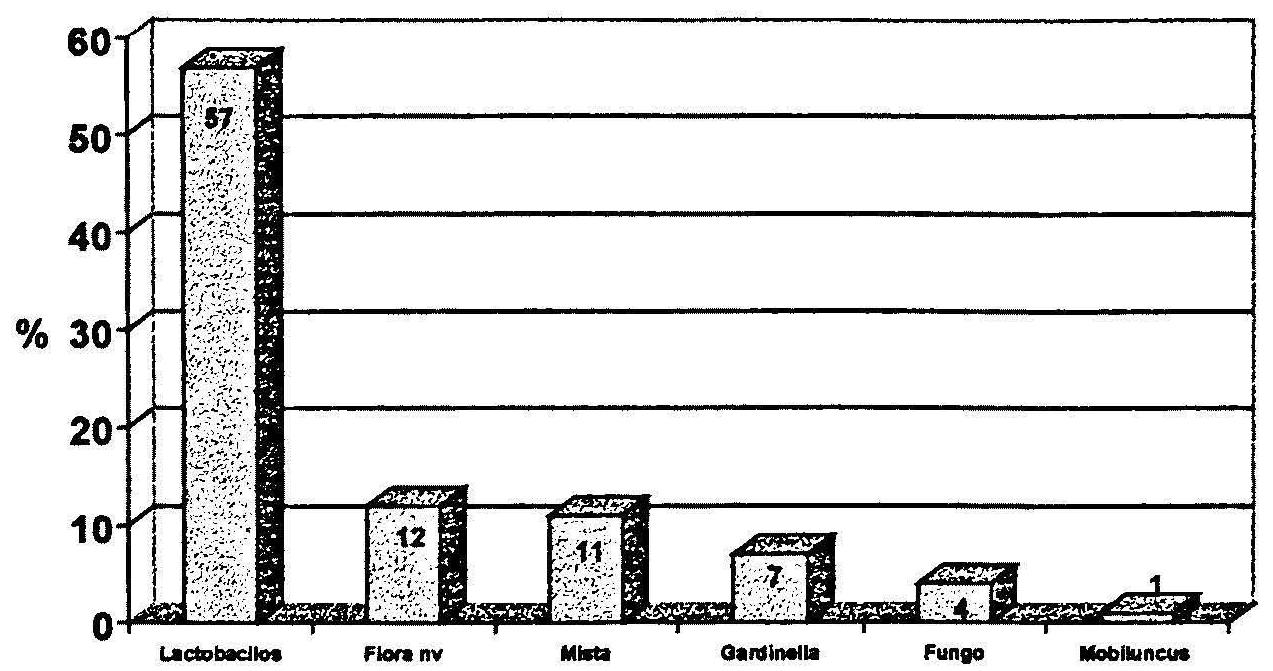

Figura 3 - Distribuição percentual dos exames de citologia oncológica de acordo com o tipo de flora vaginal. Maringá-PR, 2003.

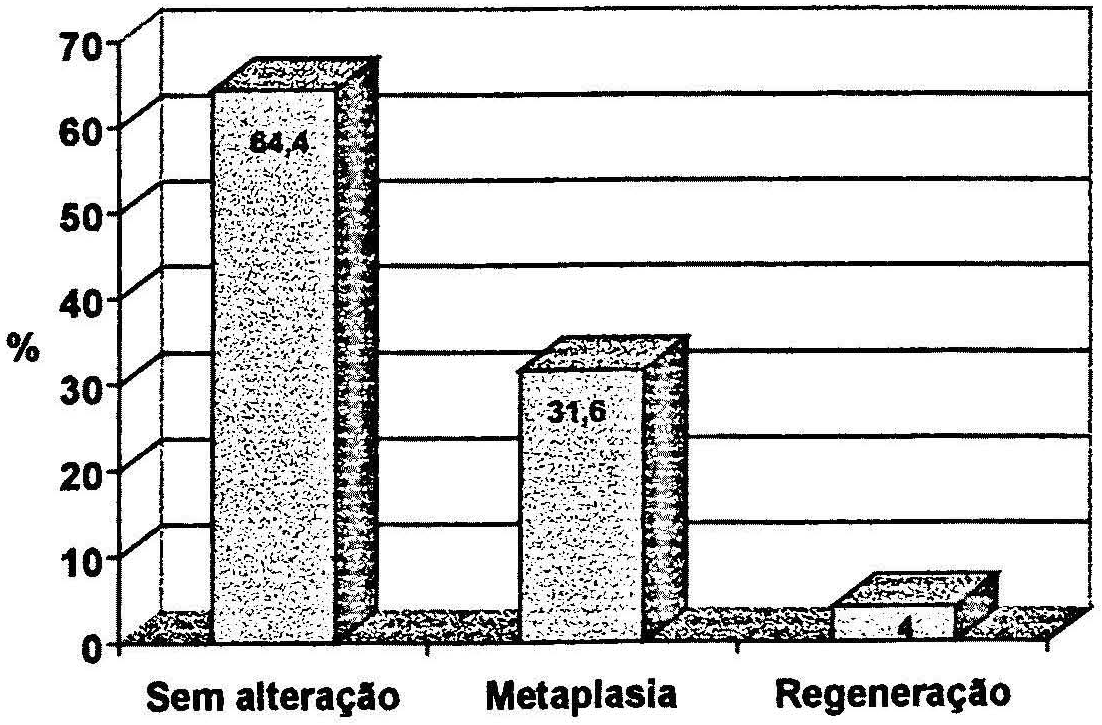

Figura 4 - Distribuição percentual dos exames de citologia oncológica de acordo com processos benignos. Maringá-PR, 2003. 


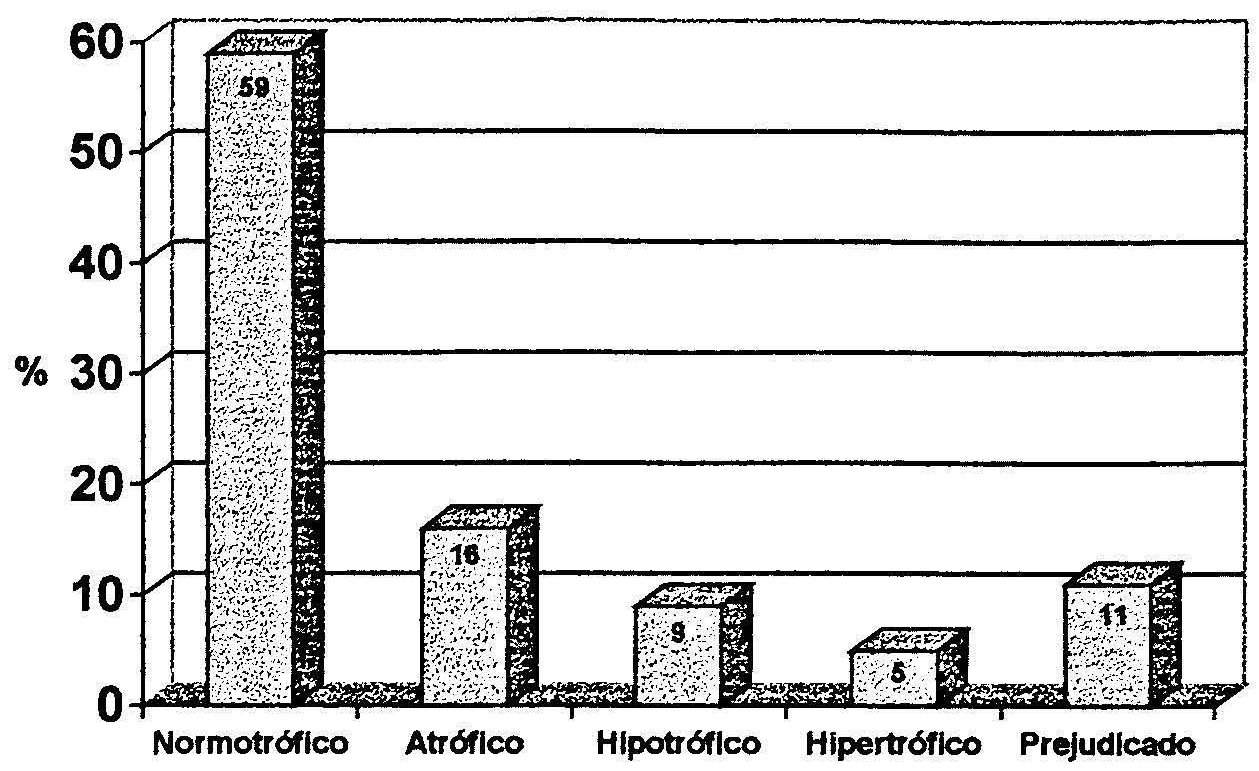

Figura 5 - Distribuição percentual dos exames de citologia oncológica de acordo com o trofismo. Maringá-PR, 2003.

\subsection{Reação em Cadeia da Polimerase (PCR)}

Foram realizadas 73 pesquisas de DNA de HPV, de amplo espectro de genótipos, por reação de cadeia da polimerase (PCR). Quinze mulheres se recusaram a pesquisá-lo. Foram realizadas novas coletas em 6 mulheres, porque os resultados não foram conclusivos. Todas as reaçōes resultaram negativas para DNA de HPV, assim, nenhum caso de HPV foi encontrado no material analisado. 


\section{DISCUSSÃO}

Este é o primeiro estudo que avaliou a prevalência de HPV em auxiliares de serviços gerais da Universidade Estadual de Maringá com idade de 40 - 60 anos. A população de estudo foi de 88 mulheres que se submeteram ao inquérito. Apesar de ter sido testado, o questionário apresentou algumas deficiências observadas quando da análise de dados. 0 intuito inicial era de pesquisar a prevalência de HPV em fumantes e não fumantes, o questionário apresentou excesso de perguntas sobre o tema, além das relacionadas aos antecedentes familiares.

Quando se perguntava se havia feito cauterização, as respostas eram espontâneas, sem constrangimentos, mas em se tratando do relato de ter contraido o HPV, as mulheres (7) se mostraram bastante constrangidas, ora agressivas, ora justificando que já estavam curadas. Uma das mulheres relatou estar fazendo terapia psicológica. O comportamento dessas mulheres nos faz refletir sobre o estigma que carrega esse tema cujo temor principal é o desenvolvimento do câncer e o ressentimento ao parceiro que o transmitiu (FERNANDEZ-ESQUER e cols. 2000). Estudos para mudança de comportamento frente à infecção por HPV deverão ser desenvolvidos desde que apenas $1 \%$ de todas as infecções poderá eventualmente desenvolver 0 câncer (JOSEFSSON e cols. 2000). 
Apesar de abarcar quase a totalidade $(86,4 \%)$ da populaçăo referente a auxiliares de serviços gerais, deve-se considerar como uma população institucional por não representar a população de Maringá.

Da populaçåo que respondeu ao questionário, 12 mulheres se recusaram terminantemente a submeter-se ao exame colpocitológico. Algumas só fariam, se a coleta da secreção cérvico-vaginal fosse feita pelo ginecologista delas (tentativas frustradas por não ter sido possível agendar a coleta com os mesmos), outras se recusaram a se expor ao laboratório da universidade por ser uma unidade de ensino onde muitos estudantes estagiários atendem a população.

Em relação ao exame de PCR mesmo conhecendo o procedimento de coleta que seria simultâneo à coleta cérvico-vaginal, 3 mulheres não autorizaram a pesquisa de DNA do vírus. Essa atitude nos reporta para uma outra dimensão, ou seja, o medo de que o resultado seja positivo ou de que outras pessoas conheçam o resultado (algumas das declarações constatadas). Assim, pode o inquérito trazer alguns vieses, inerentes ao comportamento das pessoas entrevistadas. Apesar dessas criticas, somos adeptos de que a entrevista é um bom instrumento porque trouxe a caracterização da população em estudo. PEREIRA (1995) confirma o exposto, relatando que o inquérito é bastante útil quando utilizado com o objetivo de suplementar as afirmaçōes, gerando dados de que se necessita. Justifica-se assim, o uso desse instrumento para se conhecer o comportamento sexual das mulheres na fase climatérica em relação a infecção por HPV . 
Este estudo avaliou a prevaléncia de HPV em mulheres no climatério, período de vida com poucos estudos pertinentes. Partindo do pressuposto de que casais nessa fase, por motivos vários, têm atividade sexual reduzida e que - cônjuge pode desempenhar eventuais relaçōes extraconjugais, o que se espera é uma freqüência baixa em doenças sexualmente transmissiveis (DST). Os resultados mostraram que a freqüência do HPV, em 73 mulheres na faixa etária de 40-60 anos foi negativa (igual a zero) para uma população em que $43,2 \%$ estava na idade fértil, $45,5 \%$ com menarca após 14 anos de idade, $47,7 \%$ teve a primeira relação sexual após 20 anos, $62,5 \%$ sem nenhum método contraceptivo, $53,4 \%$ eram multiparas, $37,5 \%$ de tabagistas, $37 \%$ com renda familiar menor ou igual a um salánio minimo e $77,0 \%$ com atividades sexuais tiveram apenas um parceiro nos últimos 3 anos.

Em se tratando do Município de Maringá, cuja população está em tomo de 303.551 habitantes (PREFEITURA DO MUNICÍPIO DE MARINGÁ 2005), os dados de janeiro de 2004 mostraram que a freqüência de HPV é pequena. De 1.177 exames preventivos realizados, houve apenas um caso do vínus; sendo 1.168 dentro da nomalidade $(99,2 \%) ; 6$ casos de atipias de células escamosas de significado indeterminado (ASCUS); 1 neoplasia intraepitelial de grau I (NIC 1) e 2 casos de neoplasia intraepitelial de grau II (NIC II), assim, a freqüência de alterações citológicas e de HPV é relativamente baixa na região (SECRETARIA DA SAÚDE DO ESTADO DO PARNÁ 2004). Quanto a esses dados, é preciso considerar que estão distribuidos na população como um todo, sem considerar a faixa etária. Este estudo avaliou apenas a população de 40-60 anos da 
Universidade Estadual de Maringá. A freqüência do Papilomavirus humano tem sido observada, preferencialmente, em mulheres no menacme e sexualmente ativas; e a literatura tem mostrado que a ela é inversamente proporcional com o aumento da idade (GROSS e BARRASSO 1999; NAUD e cols. 2000; SCHIFFMAN E CASTLE 2003).

No mundo, porém, a cada ano milhőes de pessoas adquirem doenças sexualmente transmissíveis. O impacto negativo na economia, causado por essas doenças nos Estados Unidos, em 2000, foi de 6,5 bilhőes de dólares gastos com 9 milhões de casos novos ocorridos em jovens na faixa de 15-24 anos (CHESSON e cols. 2004). Esses autores mostraram que $90,0 \%$ das DST foram causadas pelos vírus do HIV e HPV, com custo de 5,9 bilhőes de dólares. Esses dados nos reportam para a importância de se conhecer exatamente onde alocar os recursos.

Entre os poucos estudos em mulheres no climatério, existem três estudos que, apesar de constatarem resultados discordantes, podem dimensionar a dificuldade de se estabelecer a freqüência e a padronização de metodologias utilizáveis para exame preventivo em saúde pública.

UTAGAWA et cols. (1997) estudaram as alteraçōes citológicas de 1503 exames de mulheres acima de 50 anos. Os sinais citológicos sugestivos de infecção por HPV foram encontrados em 5,5\% e quando submetidos à hibridização in situ 1,5\% apresentaram o DNA do virus. Os autores ressaltaram que a acuidade diagnóstica da citologia é menor no climatério pela dificuldade de obtenção da amostra pela regressão apresentada pelo epitélio. A população 
nesse estudo foi previamente selecionada pela citologia por apresentarem características sugestivas de HPV explicando assim a prevalência de 1,5\% na pesquisa do DNA do vírus. Foram pesquisadas as alteraçōes citopáticas do HPV, porém, no presente estudo, não foi observada nenhuma alteração sugestiva daquele vírus. Diferentemente deste, na pesquisa desenvolvida por UTAGAWA e cols. (1997) não foram estudadas os aspectos epidemiológicos e demográficos além da idade das mulheres que se limitou a 50 anos ou mais. Como também no estudo de SYMMANS e cols. (1992), que correlacionando a citologia com a histologia constataram apenas um caso $(6 \%)$ de DNA do HPV das 17 mulheres pré-menopáusicas com atipias citológicas selecionadas por colposcopia. Duas apresentaram lesð̄es intrapiteliais cervicais quando submetidas à biópsia. No mesmo estudo os autores encontraram resultados equivalentes em 47 mulheres pós-menopausadas que haviam se submetido à histerectomia por motivos não associados. Constataram, ainda, que o víns esteve presente de forma semelhante tanto nas pré como nas pósmenopáusicas. Portanto, nem sempre as atipias estão associadas à presença do virus, representando apenas, alteraçōes inflamatórias atróficas, principalmente relacionadas a de colpites senis, que são muito freqüentes em esfregaços citológicos em mulheres no climatério. JOVANOVIC e cols. (1995), ACS e cols. (2000) sugerem que pela existência dessas dificuldades diagnósticas na interpretação dos esfregaços da pós-menopausa, estudos acurados devem ser desenvolvidos para o estabelecimento de critérios diagnósticos reprodutíveis e bem padronizados. 
Vale lembrar que o processo seletivo da população e a metodologia empregada no trabalho de SYMMANS e cols. (1992) quanto de UTAGAWA e cols. (1997) diferem deste estudo.

A casuística do estudo de Maringá contradiz por outro lado à população polonesa estudada por ZIETKOWIAK e cols. (2002). Esses pesquisadores encontraram no estudo com 90 mulheres, um pico de infecção com HPV de $48,5 \%$ no grupo de 45 a 49 anos e $26,1 \%$ em mulheres com 56 anos ou mais. Por outro lado, LAZCANO e cols. (2001) num estudo em 33 municípios do Estado de Morelos no México pesquisaram o HPV em 1340 mulheres com diagnóstico citológico normal. Utilizando o PCR do tipo reverso, os autores encontraram 27 (2,01\%) casos de HPV sendo 17 de alto risco e 10 de baixo risco. Em relação à freqüência de HPV por idade, eles encontraram $23 \%$ e $16,7 \%$ em mulheres com idade inferior a 25 anos e com 65 anos ou mais respectivamente. Relataram ainda, que o HPV de baixo risco foi linearmente mais freqüente com a idade das mulheres. A principal variável em todas as idades associadas aos dois tipos do vírus foi o número de parceiros sexuais.

Comparando os resultados com os de LAZCANO e cols. (2001) pode-se reforçar a idéia de que parceiros únicos traduzem baixa freqüência de HPV como observado no estudo.

Isso acrescenta outra singularidade nesse estudo; pois os trabalhos realizados por SYMMANS e cols. (1992), UTAGAWA e cols. (1997) e LAZCANO e cols. (2001) utilizaram metodologias diagnósticas diferentes, respectivamente, citologia, histologia, colposcopia com hibridizaçăo in situ; 
citologia e hibridização in situ; citologia e PCR do tipo reverso. Por outro lado, ZIETKOWIAK e cols. (2002) apesar de diagnosticar HPV por citologia e PCR, estudaram apenas a população que apresentavam atipias citológicas para realizar a pesquisa do DNA do virus.

Portanto, o presente trabalho se toma original por discriminar a citologia ө a pesquisa de virus por PCR em mulheres na fase de climatério apresentando os aspectos epidemiológicos e demográficos.

O estudo de LAZCANO e cols. (2001) conclui que entre as jovens o aumento no número de gravidez associa-se a HPV de baixo risco, porém, entre as de mais idade a condição sócio-econômica baixa esteve relacionada com o aumento da freqüência de HPV, particularmente entre 35 a 54 anos. O estudo de Maringá sugere que a condição sócio-econômica está relacionada à freqüência de HPV pela ausência $(0 \%)$ de casos do vírus, no entanto, lembrando que nesse estudo $13,6 \%$ de mulheres se negaram a participar da pesquisa de DNA do virus, assim, há que se considerar o desconhecimento do resultado relativo àquelas mulheres.

Ressalte-se que neste estudo seguiu-se critério metodológico rigoroso quanto à homogeneidade do grupo em relação à idade e ao período de vida da mulher (o climatério). A análise microscópica da colpocitologia oncológica foi realizada por dois profissionais experientes e a PCR sob controle rigoroso de assepsia e anti-sepsia e ensaios controles para testar as condiçōes internas de reação. 
KOUTSKY (1997) relatou que em mulheres com manifestação clínica (lesões genitais visiveis) é possível encontrar HPV em 1,0\% dos adultos sexualmente ativos sendo que esse percentual pode elevar-se à $15,0 \%$ pela pesquisa do DNA do vírus. BONFIGLIO e EROZAN (1997) por outro lado, apresentaram uma prevalência de 20 a $40 \%$ salientando que esse vírus se encontrava em significante estado emergente. Para VILLA (1995) a prevalência era de 15,0 a $40,0 \%$, sendo maior nas mulheres jovens e adolescentes. 0 estudo conduzido por MUNOZ (2000) em 22 países, encontrou dois picos de prevalência; em mulheres menores de 25 anos e maiores de 59 anos na Costa Rica, México e Colômbia. ALVARENGA e cols. (2000) por outro lado, sugeriram de 40,0 a $70,0 \%$ à presença de HPV associados às neoplasias intraepiteliais cervicais de baixo grau (NIC I).

Sugerindo maiores estudos, os trabalhos de SMITH e cols. (1997, 2003, 2004) recomendaram o diagnóstico periódico de HPV em mulheres pósmenopausa, uma vez que nessas mulheres a freqüência é alta e por apresentarem risco de desenvolvimento de câncer de colo uterino especialmente naquelas que fazem uso prolongado de terapia de reposição hormonal. Mesmo näo encontrando nenhum caso de HPV houve $26,1 \%$ de usuárias de hormônio. Há limitação neste estudo por não permitir especificar o tempo de uso, o tipo de hormônio bem como a sua dosagem. Porém, considerando que $62,5 \%$ não faziam uso de qualquer hormônio além de $11,4 \%$ laqueadas, os resultados explicam a baixa freqüência de HPV. 
Baseado na literatura existente, a prevalência do HPV na população varia conforme a população estudada e o método utilizado para a sua detecçăo (DILLNER e cols. 2000).

$\mathrm{Na}$ preocupação de determinar a sensibilidade, a especificidade e o custo/eficiência do diagnóstico para o exame preventivo de câncer de colo de útero, tem-se sugerido, nas últimas décadas, a inclusão de testes de biologia molecular na detecção de HPV.

SUZUKI (2000), estudando pacientes com atipias sugestivas de neoplasia intrapiteliais, avaliou a eficiência da colpocitologia utilizando os critérios morfológicos (coilocitose, a disqueratose e a discariose) comparando-a com a técnica de PCR. A vantagem dessa técnica é que uma cópia do DNA viral é multiplicada em milhōes de cópias. Por outro lado, exige cuidados técnicos no sentido de minimizar ao máximo os contaminantes para evitar resultados falsos positivos, com o inconveniente de não proporcionar a quantificação do virus. Porém, é uma técnica recomendada para populações que apresentam amostras com carga viral pequena na ordem de $250 \mathrm{ng}$ a $1 \mu \mathrm{\mu g}$ de DNA, como no presente estudo. SUZUKI (2000) encontrou uma sensibilidade de $80,0 \%$; especificidade de $89,80 \%$ e valor preditivo positivo de $61,5 \%\left(\chi^{2}=23,6\right.$ e $\left.p<0,0001\right)$, comprovando que o uso do método citológico de Papanicolaou aliado ao PCR traz grandes benefícios diagnósticos na detecção do HPV. Porém, MAXWELL e cols. (2002) relataram que quanto maior a sensibilidade do teste usado, maior o custo. Contudo, um teste mais sensivel 
utilizado com alguma freqüência traz maiores beneficios comparados à citologia realizada anualmente (MYERS e cols. 2000).

Há consenso de que o exame preventivo seja a forma mais efetiva para a redução da incidência e mortalidade por câncer do colo uterino e está claro que o diagnóstico de HPV é muito importante nesse processo (BOYLE e cols. 2003). A literatura mostra que aumentando o rastreamento e a tipificação dos HPV oncogênicos há uma redução do número de cânceres colo uterino. Porém, a rotina clínica depara-se com uma outra dificuldade, ou seja, como agir frente às lesర̃es de significado indeterminado cuja freqũência é relativamente alta. HERBEST e cols. (2001) relataram que a pesquisa de HPV para gerenciamento da rotina clínica dos esfregaços citológicos para atipias em células escamosas de significado indeterminado (ASCUS) não é garantia de sua detecçăo. Não sendo possivel uma comparação exata entre a triagem de HPV e o protocolo utilizado para acompanhamento e direcionamento dessas lesões. Assim, persistem as dificuldades de procedimento quanto ao tema. Porém, apesar de dispendioso, a AMERICAN CANCER SOCIETY (2005) sugere a citologia em base líquida e o teste reflexo, para melhorar a detecção de lesð̋es intraepileliais, para minimizar as dificuldades relativas a ASCUS.

Em relação a infecção do HPV a condição de maturidade hormonal do epitélio cérvico-uterino parece favorecer a infecção por HPV, assim, UTAGAWA e cols. (1997) estudaram 119 mulheres com mais de 50 anos e encontraram $5,9 \%(7)$ de atróficos, $42,0 \%(50)$, hipotróficos e $52,1 \%$ (62) tróficos. Os 7 casos atróficos apresentavam quadro com alteraçōes sugestivas de HPV. Apesar do 
pequeno número, os autores sugerem que o resultado corrobora naquele sentido. Nesse estudo $16 \%$ (12) foram atróficos, $9 \%$ (7) hipotróficos; $59 \%$ (45) tróficos e $5 \%$ (4) hipertróficos, sendo $11 \%$ (8) das amostras não realizadas, por apresentarem condições inadequadas de avaliação citológica hormonal.

Aventa-se, ainda, a possibilidade do epitélio metaplásico facilitar a infecção por HPV, porém, poucos estudos existem sobre o tema. A metaplasia da cérvice uterina é um processo de reconstrução do epitélio cuja etiologia e significado biológico permanece obscuro e parece favorecer a infecção pelo HPV (NY e cols. 2002). Estes autores estudaram mulheres na peri e pós menopáusicas detectando a metaplasia por citologia e histologia com o intuito de verificar a correlação com HPV. A presença do DNA do vírus foi constatada em todas as amostras, quando submetidas ao PCR. Apesar da casuistica não representativa (7), os autores afirmaram que metaplasia de colo uterino estaria relacionada com a infecção de HPV, sugenindo, porém, maiores investigaçōes. Por outro lado, CONSOLARO e cols. (2001) em 48 metaplasias encontraram DNA de HPV em 7 casos. Das 76 citologias realizadas, no presente estudo observaram-se, 24 casos $(31,6 \%)$ de metaplasias e nenhum caso de HPV. Há que considerar que a população era constituída por 88 mulheres e que algumas das 12 mulheres $(13,6 \%)$ que se recusaram a pesquisa do DNA de HPV poderiam ser positivas.

Em relação a processos infecciosos no climatério, CARDOSO e cols. (2000) alertam para uma análise cuidadosa dos esfregaços vaginais em mulheres na idade entre 40 e 65 anos de idade. Nesse estudo com 533 
mulheres, sob a coloração de Papanicolaou CARDOSO e cols. (2000) encontraram $44,5 \%$ de vaginites determinadas por flora mista e $10 \%$ de Gardnerella vaginalis. Em Maringá foi encontrado $11 \%$ de vaginites por flora mista seguidas de $7 \%$ de Gardnerella vaginalis. Foi encontrado, ainda, $1 \%$ de Mobiluncus sp. Entre as vaginites determinadas por Cåndida sp. CARDOSO e cols. (2000) encontraram 27,3\%4\%; seguida de $12,6 \%$ de Trichomonas vaginalis; freqüências consideradas altas, desde que foi encontrado apenas $4 \%$ do fungo e nenhum caso desse protozoário. Diante de seus resultados CARDOSO e cols. (2000) recomendam uma análise criteriosa dos esfregaços colpocitológicos em mulheres no climatério uma vez que os processos infecciosos os mais diversos podem estar presentes pelo favorecimento do epitélio atrófico.

As infecções por HPV por outro lado, podem estar associadas às mais diversas alterações do colo uterino; O DNA do HPV pode ser detectado em um grande percentual das lesões cervicais variando de 40,0 a $70,0 \%$ para as neoplasias intraepiteliais cervicais de baixo grau. ALVARENGA e cols. (2000) relatam que de 3.287 casos de infecções no colo do útero, 381 apresentaram HPV associados a diferentes afecções; $29,1 \%$ das quais representaram cervicites; $25,1 \%$ associados ao NIC I (Neoplasia Intraepitelial Cervical) e $14,1 \%$ ao NIC II; 34,0\% NIC III e 1,8\% ao carcinoma in situ. Em Maringá apenas um caso de NIC III ocorrido no passado, relatado em entrevista, cujo DNA do 
HPV não foi detectado nem as alterações citopáticas patognomônicas da infecção foram encontradas.

As lesőes de significado indeterminado que săo lesőes relativamente freqüentes em exames preventivos constatam-se grandes dificuldades de definição e acompanhamento. Porém, LONKY e cols. (2003) num estudo de 8170 citologias, encontraram cerca de $30,0 \%$ (278) de células escamosas atipicas de significado indeterminado (ASCUS) entre as quais numa pesquisa mais apurada apresentaram $11,9 \%$ de NIC II ou III e $17,6 \%$ de NIC I. Assim, muitas das lesões de significado indeterminado podem estar mascarando processos mais sérios, ligados a neoplasias intra-epiteliais cervicais.

Neste estudo há que se considerar a baixa freqüência do HPV principalmente nos padrões de mulheres com parceiro único e estável, não fumante, início da atividade sexual tardia, exame de Papanicolaou sem atipias. E ainda, mulheres que se submetem ao exame preventivo com regularidade. Mesmo com amostragem que não se possam inferir à população, os dados reforçam a literatura para que esse perfil de mulheres que apresentavam dois exames consecutivos negativos, o próximo exame poderá ser após 3 anos. Essas medidas são consideradas seguras e trarăo com certeza, uma economia substancial nos recursos para saúde (AMERICAN CANCER SOCIETY 2005).

Apesar da metodologia rigorosa empregada neste estudo e da casuística expressar quase a totalidade da população $(84,6 \%)$ delimitada pela idade, 0 trabalho mostra também, que as dificuldades ou limitaçöes para coleta 
adequada de material para $\mathrm{CO}$, além do seu diagnóstico, justificada em trabalhos de outros autores, não é consistente uma vez que quando realizada de forma criteriosa, por profissionais experientes, obtém-se material adequado na maioria dos casos (GOMPEL e KOSS 1997; MONTELEONE e VALENTE 1998).

A relevância clínica deste trabalho consiste em mostrar que mulheres no climatério cujo exame preventivo (CO) é classe I ou II de Papanicolaou e sem atipias celulares, os testes de detecção de DNA do HPV será negativo; e, portanto, os recursos para os programas preventivos de câncer de colo de útero para mulheres com perfil epidemiológico semelhante a esta casuistica podem ser direcionados de forma racional e económica.

Estes resultados não permitem fazer ilações sobre a realização de $\mathrm{CO}$ ou testes de detecção do HPV para mulheres que não se encontram no climatério e com fatores de risco diferentes dos analisados nesta pesquisa. 


\section{CONCLUSÃO}

A freqüência de Papilomavirus em auxiliares de serviços gerais da Universidade Estadual de Maringá, com acesso a programa de rastreamento de câncer do colo uterino, na faixa etária de 40 a 60 anos e que apresentaram os exames preventivos normais e apenas inflamatórios foi zero.

Este estudo permite sugerir que as mulheres com este perfil não têm indicação para pesquisa de DNA do HPV. 


\section{REFERÊNCIAS}

Acs G, Grupta PK, Baloch ZW. Glandular and squamous atypia and intraepitelial lesions in atrophic cervicovaginal smears. One institution's experience. Acta Cytol 2000; 44(4):611-7.

Alvarenga GC, Sá EMM, Passos MRL, Pinhero VMS. Papilomavírus humano e carcinogênese no colo do útero. J Bras Doen Sex Transm 2000; 12(1):28 38.

American Cancer Society. Can cervical cancer be prevented? [on line]. Available from:http:I/huw.cancer.org/dicroot/CRI/conyent/CRI $242 X$ Can ce vical cancer be pre... [2005 jan 4].

Barton SE, Jenkis D, Cuzick J, Maddox PH, Edwards R, Singer A. Effect of cigarette smoking on cervical epithelial immunity: a mechanism for neoplastic changes? The Lancet 1988; 17:652-4.

Bauer HB, Manos MM. PCR detection of genital human papilomavirus. In: Persing DH, Smith TF, Tenover FC, WhiteTJ. Diagnostic molecular microbiology principles and applications. Mayo Foundation Rochester: 1993.

Bonfiglio TA, Erozan YS. Gynecologic cytopathology. Philadelphia: LippincottRaven; 1997.

Borges SCV, Melo VH, Mortoza Junior G, Abranches A, Lira Neto JB, Trigueiro MC. Taxa de detecção do Papiomavírus humano por captura hibrida II em mulheres com neolasia intraepitelial cervical. RBGO 2004; 26:105-110.

Boyle $P$, Leon ME, Maisonneuve P, Autier P. Cancer control in woman. It $J$ Gynecol Obstet. 2003; 83 Suppl 1: 179-202. 
Brinton LA, Hamman RF, Huggins GR, Lehman HF, Levine RS, Mallin K, Fraumeni JF Jr. Sexual and reprodutive risk factors for invasive squamous cell cervical cancer. J Natl Cancer Inst 1987;97: 23-30.

Brinton LA, Reeves WC, Brenes MM, Herrero R, Gaitan E, Tenorio F et al. The male factor in the etiology of cervical cancer among sexually monogamous women. Int J Cancer 1989a; 44: 199-203.

Brinton LA, Reeves WC, Bienes MM, Herrero R, de Briton RC, Gaitan E et al. Parity as a risk factor for cervical cancer. Am J Epidemiol 1989 b;130: 486-96.

Burger MPM, Hollema H, Gouw ASH, Pieters WJLM, Quint WGV. Cigarette smoking and human papillomavirus in patients with reported cervical cytological abnormality. BMJ 1993; 306: 749-52.

Cardoso MSR, Ramos ESN, Castro ADP, Ramos DKN, Silva DGC, Cavalcanti Júnior GB. Prevalência de vaginites específicas e inespecíficas em mulheres na pós-menopausa. Rev Bras Anal Clin 2000; 32(4): 275-7.

Carvalho JM, Oyakawa N (ed.) I Consenso Brasileiro de HPV. BG Cultural. $1^{\text {a }}$ ed. São Paulo; 2000; 142.

Chesson HW, Blandford JM, Gift TL, Tão G, Irwin KL. KL. The estimated direct medical cost of sexually transmitted diseases among American youth, 2000. Perspect Sex Reprod Health 2004; 36(1):11-9.

Chow VTK, Loh E, Yeo WM, Tan SY, Chan R. Identification of multiple genital HPV types and nested type-specific PCR coupled with cycle sequencing. Pathology 2000; 32: 204-8. 
Consolaro MEL, Suzuki LE, Kaneshima EM, Tognin MCB, Bosco JS, Silva FM. Detection of human papillomavirus through the test of papanicolaou and pcr in the inespecific inflammatory processes and with squamous metaplasia. The nucleus $2001 ; 44: 141-7$.

De Brux J, Orth G, Croissant $O$, Cochard B, lonesco $M$. Lesions condylomatoteuses du colo uterine evolution chez 2466 patients. Bull Cancer 1983; 70: 410-22.

De Sanjos S, Palefsky J. Cervical and anal HPV infection in HIV positive women and men. Virus Res 2002; 89(2): 201-11.

Dillner J, Meijer $\mathrm{CJ}$, von Krogh $\mathrm{G}$, Horenblas S. Epidemiology of human papillomavirus infection. Scand J Urol Nephrol Suppl. 2000; (205): 194-200.

Eppel W, Worda C, Frigo P, Ulm M, Kucera E, Czenwenka K. Human Papillomavirus in the cervix and placenta. Obstet Gynecol 2000; 96: 337-4.

Fernandes-Esquer ME, Ross MW, Torres I. The importance of psychosocial factors in the prevention of HPV infection and cervical cancer. Int J STD AIDS 2000; 11: 701-13.

Garcia MAA, Rodrigues MG, Borega, RS O envelhecimento e a saúde. Rev ciências médicas 2002: 11(3): 221-31.

Goldie SJ, Kim JJ, Wright TC. Cost- effectiveness of human papillomavirus DNA testing for cervical cancer screening in women aged 30 years or more. Obstet Gynecol 2004; 103(4): 617-8. 
Gompel C, Koss L. Citologia Ginecológica e suas bases anatomoclínicas. São Paulo: Manole; 1997.

Gonçalves MAG. Prevalência da infeç̧ăo pelo papilomavirus humano (HPV) e da neoplasia intraepitelial genital em amostras de mulheres HIV positivas da cidade de Santos, SP. São Paulo; 1998.[Tese de Doutorado Faculdade de Saúde Pública da USP].

Gross GE, Barrasso R. Infecção pelo papilomavírus humano: Atlas clínico de HPV. Porto Alegre: Artes médicas; 1999.

Herbst AL, Pickett KE, Follen M, Noller KL. The management ASCUS cervical cytologic abnormalities and HPV testing: a cautionary note. Obstet Gynecol. 2001;98:849-51.

Holowaty $P$, Miller $A B$, Rohan T, To T. Natural history of dysplasia of the uterine cervix. J Natl Cancer Inst 1999; 91(3): 252-8.

Josefsson AM, Magnusson PK, Ylitalo N, Sorensen P, Qwarforth-Tubbin P, Andersen $\mathrm{PK}$, et al. Viral load of human papilloma virus 16 as a determinant for development of cervical carcinoma in situ: nested case-cont study. Lancet 2000; 355 (9222):2189-93

Jovanovic AS, McLachlin CM, Shen L, Welch WR, Crum CP. Postmenopausal squamous atypia: a spectrum including "pseud koilocytosis". Mod Pathol 1995; 8: 408-12.

Kaneshima EN, Bidoia CCG, Gabriel M, Suzuki LE, Consolaro MEL. Aplicação do método PCR-RFLP para tipagem de HPV em infecçöes cervicais de 
pacientes atendidas no LEPAC, Universidade Estadual de Maringá. Acta Scientiarum 2001; 23:731-7.

Kim JJ, Wright TC, Goldie SJ. Cost-effectiveness of alternative triage strategies for aypical squamous cells of undetermined significance. JAMA 2002; 287: 2428-9.

Koskela $P$, Anttila $T$, Bjorge $A$, Dillner $J$, Hakama $M$, Hakulinen $T$, et al. Chlamydia trachomatis infection as a risk factor for invasive cervical cancer. Int J Cancer 2000; 85(1): 35-9.

Koutsky L. Epidemiology of genital human papillomavirus infection. Am J Med 1997; 102 (5A): 3-8.

Kurman RJ, Solomon D. O Sistema Bethesda para o relato de diagnóstico citológico cervico vaginal. Definiçōes, critérios e notas explicativas para terminologia e amostra adequada. Rio de Janeiro: Revinter, 1997.

Lazcano PE, Herrero R, Munoz N, Cruz A, Shah KV, Alonso $P$ et al. Epidemiology of HPV infections among Mexican women with normal cervical cytology. Int J Cancer 2001; 91:412-20.

Lonky NM, Felix JC, Naidu YM, Woldie-Tsadik G. Triage of atypical squamous cells of undetermined significance with hybrid capture II: colposcopy and histologic human papillomavirus correletion. Obstet Gynecol 2003; 101:481-9.

Manos MM, Ting $Y$, Wrigt DK, Lewis AJ, Broker TR, Wolinsky SM. Use of polymerase chain reaction amplification for the detection of genital human papillomaviruses. Cancer cells 1989; 7:209-14 
Maxwell GL, Carison JW, Ochoa M, Krivak T, Rose GS, Myers ER. Costs and effectiveness of altemative strategies for cervical cancer screening in military beneficiaries. Obstet Gynecol 2002; 100:740-8.

Menezes AMB, Horta BL, Oliveira ALB, Kaufmann RAC, Duquia r, Diniz A et al. Risco de câncer de pulmāo, laringe e esôfago atribuivel ao fumo. Rev Saúde Pública 2002; 36: 129-34.

Ministério da Saúde. Câncer do colo uterino [on line]. Rio de Janeiro; 2005. Disponivel em: http://mmw.inca.gov.br/conteudo view.asp?ID+326 [15/01/2005].

Ministério da Saúde. Normas e recomendaçőes do Instituto Nacional de Câncer/MS. Brasilia (DF); 2000; 46 (11).

Ministério da Saúde. O Programa Viva Mulher. [on line]. Brasília; 2004. Disponivel em; http://unw.inca.pr.gov.br/viva-mulherl [25/06/2004].

Monteleone PPR, Valente CA. Infectologia em ginecologia e bstetricia São Paulo: Atheneo; 1998.

Munoz N. Human papillomavins and cancer. the epidemiological evidence. J Clin Virol 2000; 191(2): 1-5.

Myers ER, Mccrory DC, Subramanian S, Mcall N, Nanda K, Datta S, Matchar DB. Setting the target for a better cervical screening test:characteristics of a cost-effective test for cervical neoplasia screening. Obstet Gynecol 2000; 96: 645-52.

Naud P, Hammes L, Vettorazzi J. Infecçăo pelo papilomavirus humano (HPV). Rev HCPA Fac Méd Univ Fed Rio Gd do Sul 2000; 20: 138-42. 
Ny WK, Cheng LK, Li AS, Cheung FM, Chow JC. Transitional cell metaplasia of the uterine cervix is related to human papillomavirus: molecular analysis in seven patients with cytohistologic correlation. Cancer 2002; 96: 250-8.

Oliveira HC, Lemgruber I. Tratado de ginecologia Febrasg. Rio de Janeiro: Revinter; 2001. vol 1.

Paes NR. A mortalidade por doenças infecciosas e parasitárias na população idosa brasileira. Rev Pan Salud Pública 2004; 15(4): 233-241.

Pereira MG. Epidemiologia: teoria e prática. Rio de Janeiro: Guanabara Koogan; 1995.

Pinotti JÁ, Barros ACSD. Ginecologia moderna. Rio de Janeiro: Revinter, 2004.

Pinto AP, Túlio S, Cruz OR. Co-fatores do HPV na oncogênese. Rev Assoc Med Bras 2002; 48(1): 73-8.

Prefeitura do Município de Maringá. Conheça Maringá. [on line]. Maringá; 2005. Disponivel em: http://mww.maringá.pr.gov.br/htmls/turismo/conheca/his torico-economia.htm. [10/01/2005].

Roberto Netto. Avaliação crítica do programa nacional de combate ao câncer de colo uterino do ministério da saúde do Brasil. São Paulo; 2001. [Dissertação de Mestrado - Escola Paulista de Medicina da UNIFESP]. 
Smith EM, Johnson SR, Ritchie JM, Feddersen D, Wang D, Turek LP, Haugen TH. Persistent HPV infection in postmenopausal age women Int J Ginecol Obstet 2004; 87: 131-7.

Smith JS, Muñoz N, Herrero R, Eluf-Neto J, Ngelangel C, Franceschi $S$ et al. Evidence for Chlamydia trachomatis as a human papillomavirus cofator in the etiology of invasive cervical câncer in Brasil and Philippines. J Infec Diseases 2002; 185:324-31.

SUzuki LE. A eficiéncia da técnica de papanicolaou na deteç̧ão do papillomavirus humano. Ponta Grossa; 2000. [Dissertação de Mestrado Universidade Estadual de Ponta Grossa].

Symmans F, Mechanic L, MacConnell P, DaSilva K, Stricker B, Nuovo C. Correlation of cervical cytology and human papollomavirus DNA detection in postmenopausal women. Int J Gynecol Pathol 1992;11(3): 204-9.

Takahashil M. Atlas colorido de citologia do cåncer. São Paulo: Manole; 1982.

Tenti P, Zappatore R, Migliora P, Spinillo A, Belloni C, Camevali L. Perinatal transmission of human Papilomavirus from gravidas with latent infections. Obstet Gynecol 1999; 93: 475-9.

Thomas DB, Ray RM, Koetsawang A, Kiviat N, Kuypers J, Qin Q et al. Human papillomavirus and cervical cancer in Bangkok $\mathrm{I}$. Risk factors for invasive cervical carcinomas with human papillomavirus types 16 and 18. Am J Epldemiol 2001; 153: 723-31. 
Turek LP, Smith EM. Programação genética dos Papilomavírus humaos genitais na infecção e no câncer. In: Löricz AT, Reid R, editores. Clinicas obstétricas e ginecológicas da América do Norte. Rio de Janeiro: Interlivros; 1996.

Utagawa ML, Loreto C, Maeda MYS, Kanamura CT, Longatto Filho A. Papilomavírus humano em esfregaços citológicos de mulheres acima de 50 anos: estudo morfológico e de hibridizaçăo in situ nas respectivas biópsias. J Bras Ginecol 1997; 107(4): 83-7.

Villa L. Papilomavirus humano e câncer do colo do útero. Laes Haes 1995; 97 : 60-7.

Wang $Y, Z h n Q, R a o H$. Matemal-fetal transmission of human papillomavirus. Chin Med J 1998; 111: 726-7.

Wied GL. Importance of site from which vaginal cytology smears are taken. Am J Clin Pathol 1955; 25(7): 742-50.

World Health Organization. Research on the menopause in the 1990's: Report of a WHO scientIfic group. Geneva; 1996 (WHO-Technical Report Series, 866).

World Health Organization. Countries: Brazil [on line]. Available from: http://www.who.int/coutry/bra/en . [2004 jul 25].

Zietkowiak W, Zimna K, Sroka L, Uchman P, Sajdak S. [Frequency of HPV infection of the uterine cervix among perimenopausal women in Wielkopolska region]. Ginekol Pol 2002; 73: 939-44. [Abstrat 12722378 in Pubmed]. 


\section{ANEXOS}

\section{Anexo 1}

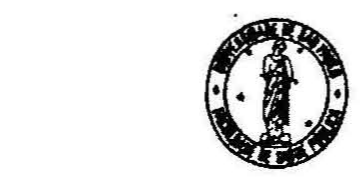

Universidade de São Paulo

Faculdade de Saúde Pública

COMITE DE ETICA EM PESQULSA - COEP

Av. Dr. Amaldo, 715 - CEP $01246-904$ - São Panlo - Brasil

Telefones: (55-11) 3066-7734-fonc/fax (55-11) 3064-7314-e-mail: mdgracas@usp.br

Of.COEP/169/02

15 de maio de 2002

Pelo presente, informo que o Comitê de Ética em Pesquisa da Faculdade de Saúde Pública da Universidade de Säo Paulo-COEP, analisou e aprovou, em sua 4."\%2 Sessato Ordinarie, realizada em 14.05.02, de acordo com os requisitos da Resoluça CNS/196/96, o Protocolo do Pesquiss $n^{\circ}$. 672, intitulado: "ESTUDO. DO PAPILOMAVIRUS HUMANO E SUA CORRRLAÇÃO COM O FUMO EM MULHERES CLIMATÉRICAS DA UNIVERSIDADE ESTADUAL DE MARINGÁPR", apresentado pela pesquisadora Linda Emiko Suzuki.

Atenciosamente,

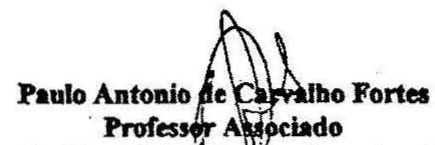

Coordenador do Comitê de Étical lem Pesquisa da FSP-COEP 


\section{Anexo 2}

\section{Universidade Estadual de Maringá \\ Pró-Reitoria de Pesquisa e Pós-Graduaçăo \\ . . \\ COMITE PERMANENTE DE ÉTICA EM PESQUISA ENVOLVENDO SERES HUMANOS}

REGISTRO N 008/2002

PARECER N $N^{\circ} 014 / 2002$

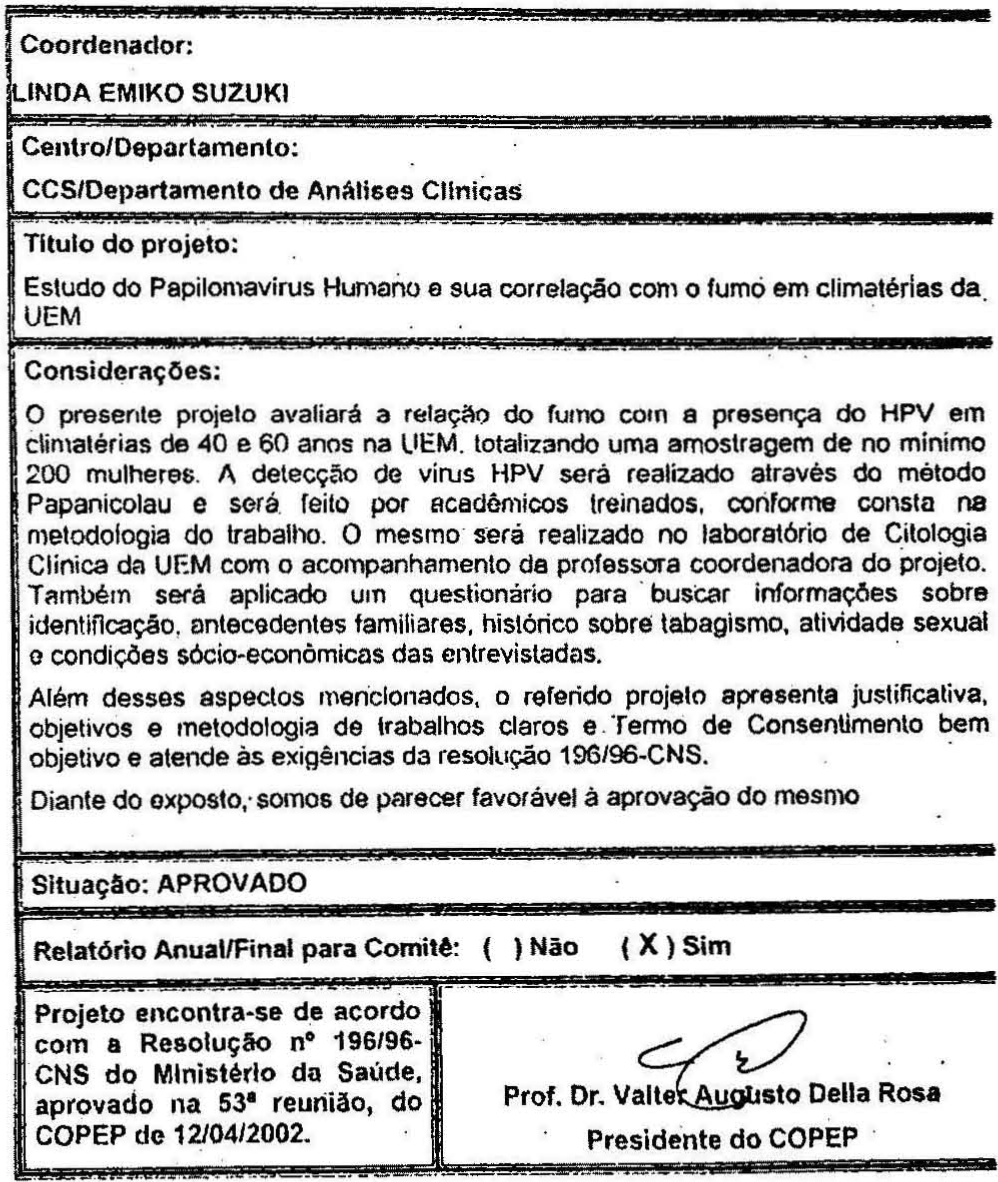




\section{Anexo 3}

\section{UNIVERSIDADE DE SÃO PAULO FACULDADE DE SAÚdE PÚBLICA DEPARTAMENTO DE SAÚDE MATERNO-INFANTIL}

\section{Termo de Consentimento Livre e Esclarecido}

Estamos realizando uma pesquisa para saber qual a freqüência de Papilomavirus humano nas mulheres com 40 anos ou mais que trabalham na Universidade Estadual de Maringá.

Será feito um questionário relacionado ao hábito de fumar e atividades sexuais. O material cérvico-vaginal será coletado. Nesse material será realizado o teste de Papanicolaou e pesquisa molecular do vírus. Esse material é normalmente coletado para a prevenção do câncer ginecológico não trazendo nenhum inconveniente ou risco ao doador.

Em casos de tratamento necessário será encaminhada ao Ambulatório Médico dessa instituição que tomará as medidas necessárias.

Será criado um banco de dados no computador estando garantido o sigilo e a privacidade às informaçð̃es fomecidas e aos resultados dos exames

Eu, apó $\mathbf{s}$ ter lido e entendido as informaçðes e esclarecidas todas as minhas dúvidas referentes a esse estudo com a Prof Linda Emiko Suzuki CONCORDO VOLUNTÁRIAMENTE participar do mesmo.

Data:

Assinatura da Participante

Nós, Prof Linda Emiko Suzuki e Dr. José Mendes Aldrighi declaramos que fornecemos todas as informações referentes ao estudo à participante. 


\section{Anexo 4}

\section{QUESTIONÁRIO DA ENTREVISTA}

\section{FACULDADE DE SAÚDE PÚBLICA-USP/UEM}

PROJETO: FREQÜÊNCIA DO FUMO E DA INFECÇÃO DO PAPILOMAVÍRUS HUMANO NA POPULAÇÃO FEMININA DA UNIVERSIDADE ESTADUAL DE MARINGÁ

\section{QUESTINÁRIO: 1 - IDENTIFICAÇÃO DA PACIENTE, RESULTADO DA ENTREVISTA}

Nome:

Setor em que trabalha:

Nome:

Data de nascimento:

Endereço: Rua:

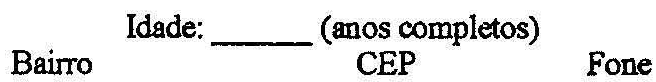
Cor: ( ) branca
( ) negra
( ) amarela
( ) mestiça
( )NS/NR

Resultado da entrevista:

Entrevistador:

1. realizada em

2. não realizada (observação do entrevistador)

3. incompleta

4. recusa

$n^{\circ}$ e resultado da entrevista

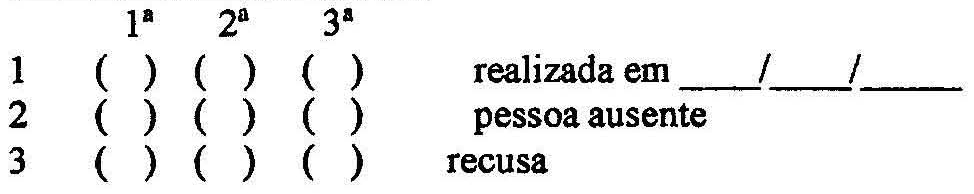

Observações do entrevistador:

Definição do diagnóstico:

Supervisão: 


\section{QUESTIONÁRIO: 2 - ANTECEDENTES FAMILIARES}

1.0 seu pai está vivo?

1 ( ) não

2 ( ) $\operatorname{sim}$ (vá para questão $n^{\circ} 3$ )

9 ( ) NS/NR (passe para questão n5)

2. Qual o motivo do seu falecimento?

3. Ele apresenta alguma doença?

1 ( ) Não (passe para questão $n^{0} 5$ )

2 ( ) Sim

9 ( ) NS/NR (passe para questão $n^{\circ} 5$ )

4. Qual o problema de saúde que ele apresenta? (anotar os 3 principais)

5. A sua mãe está viva?

1 ( ) não

2 ( ) sim (vá para questão $n^{\circ} 7$ )

9 ( )NS/NR (passe para questão $n^{\circ} 7$ )

6. Qual o motivo do seu falecimento?

7.Ela apresenta alguma doença?

1 ( ) Não (passe para questão $n^{\circ}$ 9)

2( ) Sim

9( )NS/NR (passe para questão $n^{\circ} 9$ )

8. Qual o problema de saúde que ela apresenta? (anotar os 3 principais)

9.A sra tem filhos? (vivos ou mortos)

1 ( ) Não (passe para questão 14)

2( ) Sim

9( ) NS/NR

10. Quantos?

$\mathrm{N}^{\circ}$ de filhos vivos

$\mathrm{N}^{\circ}$ de filhos mortos (se só tem filhos mortos passe para questão $\mathrm{n}^{\circ} 13$ )

11 Os filhos vivos têm alguma doença?

1 ( ) não (vá para questão $\mathrm{n}^{\circ} 14$ )

2 ( ) sim

9 ( ) NS/NR (passe para questão $n^{\circ} 14$ )

12 Quais doenças apresentam? (anotar as principais) 
\# Atenção: somente aplica a questão $n^{\circ} 13$ se houver filhos mortos

\# 13. Mortos, qual(is) a(s) causa(s) do(s) falecimento(s)?

14 A sra tem irmãos? (vivos ou mortos)

1 ( ) Não (encerra o bloco)

2 () Sim

9 ( ) NS/NR

15. Quantos?

$\mathrm{N}^{\circ}$ de irmãos vivos

$\mathrm{N}^{\circ}$ de irmãos mortos (se só tem filhos mortos passe para questão $n^{\circ} 18$ )

16. Os irmãos vivos têm alguma doença?

1 ( não (encerra o bloco)

2 ( ) sim

9 ( ) NS/NR (encerra o bloco)

17 Quais doenças apresentam? (anotar as principais)

\# Atenção: somente aplica a questão $\mathrm{n}^{\circ} 18$ se houver irmãos mortos

\# 18 Mortos, qual(is) a(s) causa(s) do(s) falecimento(s)?

\section{QUESTIONÁRIO: 3 - HISTÓRIA DE TABAGISMO}

19 A sra já fumou cigarro alguma vez?

1 ( ) Não (vá para questão n 23)

2 () Sim

9 ( ) NS/NR (passe para questão $n^{\circ} 23$ )

20 A sra fuma cigarro atualmente?

1 ( ) Não (vá para questão n²3)

2 () Sim

9 ( ) NS/NR (passe para questão $n^{\circ} 23$ )

21 Mais ou menos quantos cigarros a sra fuma por semana?

$n^{\circ}$ de vezes

1 ( ) por dia

2 ( ) por semana

3 ( ) por mês

4 ( ) por ano

9. ( ) NS/NR 
22 A sra traga o fumo?

1 ( ) Não

2 ( ) Sim

9 ( ) NS/NR

23 A sra já fumou 50 ou mais cigarros, durante toda a sua vida regularmente?

1 ( ) não (encerre o bloco)

2 ( ) sim

9 ( ) NS/NR

24 Com que idade a sra começou a fumar cigarros regularmente? anos.

25 Então a sra fuma há ____ anos desde que começou a fumar regularmente?

1 ( ) não, porque houve periodos de interrupção

2 ( ) $\operatorname{sim} \quad$ (passe para a questão $n^{\circ} 28$ )

26 Então, no total, por quantos anos a sra fuma cigarros? anos.

27 A sra sempre fumou essa mesma quantidade ( 50 ou + cigarros) ?

1 ( ) não (passe para questão ${ }^{\circ} 29$ )

2 ( ) $\operatorname{sim}$ (encerre o bloco)

9 ( ) NS/NR

28 Então, quantos cigarros a sra fumou, em geral, anteriormente? $\mathbf{n}^{\circ}$ de cigarros

1 ( ) por dia

2 ( ) por semana

3 ( ) por mês

4 ( ) por ano

9 ( ) NS/NR

(paase para a questão 37 se a entrevistada não está fumando atualmente)

29 Que tipo de cigarro a sra fuma geralmente?

1 ( ) cigarros comuns com filtro suave (baixo teor)

2 ( ) cigarros comuns com filtro

3 ( ) cigarros comuns sem filtro

9 ( ) outro - especificar PODE HAVER MAIS DE UMA RESPOSTA

30 Qual(is) marca(s) de cigarro(s) que a sra fuma? 
31 Geralmente a sra fuma

1 ( ) todo o cigarro

2 ( ) três quartos do cigarro

3 ( ) cerca de metade do cigarro

4 ( ) menos da metade do cigarro

9 ( ) NS/NR

32 Quando a sra deixa o cigarro no cinzeiro, costuma deixar que se queime sem fumar?

1 ( ) muito pouco

2 ( ) um pouco

3 ( ) uma quantidade moderada

4 ( ) muito

9 ( ) NS/NR

$33 \mathrm{Em}$ que circunstância a sra fuma?

1 ( ) no trabalho

2 ( ) em casa

3 ( ) no lazer com amigos

4 ( ) após as refeições

9 ( ) independe da hora ou local

34 Quantas horas se passou desde que a sra fumou o último cigarro? horas.

35 Quantos cigarros a sra fumou nas últimas 24 horas? cigarros.

\# Atenção somente aplicar as seguintes questões se a entrevistada não está fumando atualmente

36 Quantos anos a sra tinha quando parou de fumar da última vez? anos.

37 Quantos anos a sra tinha quando começou a fumar cigarros regularmente? anos.

38 Então a sra fumou cigarros por anos regularmente?

1 ( ) não, porque ouve períodos de interrupção

2 ( ) sim

9 ( ) NS/NR

39 Então, no total, por quantos anos a sra fumou cigarros? (a soma total dos períodos que fumou) anos. 
40 Quantos anos faz que a sra parou de fumar? anos.

41 De costume, quantos cigarros a sra fumava por dia?

1 ( ) por dia

2 ( ) por semana

3 ( ) por mês

4 ( ) por ano

9 ( ) NS/NR

42 Que tipo de cigarro a sra fumava geralmente?

1 ( ) cigarros comuns com filtro suave (baixo teor)

2 ( ) cigarros comuns com filtro

3 ( ) cigarros comuns sem filtro

9 ( ) outro - especificar PODE HAVER MAIS DE UMA RESPOSTA

43 Qual(is) marca(s) de cigarro(s) a sra fumava geralmente?

44 Geralmente a sra tragava quando fumava cigarros?

1 ( ) não

2 ( ) $\operatorname{sim}$

9 ( )NS/NR

45 A sra geralmente fumava

1 ( ) todo o cigarro

2 ( ) três quartos do cigarro

3 ( ) cerca de metade do cigarro

4 ( ) menos da metade do cigarro

9 ( ) NS/NR

46 Quando a sra deixava o cigarro no cinzeiro, costumava deixar que se queimasse sem fumar?

$\begin{array}{ll}1 & \text { ( ) muito pouco } \\ 2 & \text { ( ) um pouco } \\ 3 & \text { ( ) uma quantidade moderada } \\ 4 & \text { ( ) muito } \\ 9 & \text { ( ) NS/NR }\end{array}$

\section{OUESTIONÁRIO: 4 - TABAGISMO PASSIVO -1. MORADIA NA INFÂNCIA}

47 Quando a sra era criança, haviam pessoas que fumava na sua casa?
1 ( ) não (encerre o bloco)
2 ( ) sim
9 ( ) NS/NR (encerre bloco) 
48 Quais pessoas?

1 ( ) mãe

2 ( ) pai

3 ( ) irmãos

9 ( ) outros PODE HAVER MAIS DE UMA RESPOSTA

49 No conjunto a sra acha que essas pessoas fumavam

$\begin{array}{ll}1 & \text { ( ) pouco } \\ 2 & \text { () médio } \\ 3 & \text { ( ) muito } \\ 9 & \text { ( ) NS/NR }\end{array}$

OUESTIONÁRIO: 5 - TABAGISMO PASSIVO -H. MORADIA VIDA ADULTA

50 Outras pessoas na sua casa fumam ou fumaram, por um período maior que 6 meses?

1 ( ) não (encerre o bloco)

2 ( ) sim

9 ( ) NS/NR (encerre bloco)

51 Quais pessoas?

1 ( ) esposo

2 ( ) filho

3 ( ) irmãos

4 ( ) pais

9 ( ) outros PODE HAVER MAIS DE UMA RESPOSTA

52 Em uma semana normal, quantas horas a sra fica ou ficava em contato com pessoas que fumam em casa? horas.

Em seu trabalho horas.

53 Por quanto tempo essas pessoas fumam ou fumaram? anos

\section{OUESTIONÁRIO: 6 - BIOLOGIA E COMPORTAMENTO}

54 Com quantos anos a sra teve a menarca? anos.

55 Qual a idade do início da atividade sexual? anos.

56 Quando veio a última menstruação? 
57 A sra já sentiu ondas de calor? Com que idade começou?

58 Nos últimos 3 anos quantos parceiros sexuais a sra teve?

59 Tem parceiro sexual atualmente?

$\begin{array}{ll}1 & \text { ( ) Não } \\ 2 & \text { ( ) Sim } \\ 9 & \text { ( ) NS/NR }\end{array}$

60 Há quanto tempo está com ele?

61 A sra já teve HPV? Quando?

62 Toma algum tipo de vitamina? Qual?

63 A sra faz uso de hormônios?

1 ( ) Não Há quanto tempo a sra não usa hormônios?

2 ( ) Sim Que tipo (qual?)

9 ( ) NS/NR

\section{QUESTIONÁRIO: 7 - CONDIÇÕES SÓCIO- ECONÔMICAS}

64 Quantas pessoas colaboram com dinheiro para as despesas da casa?

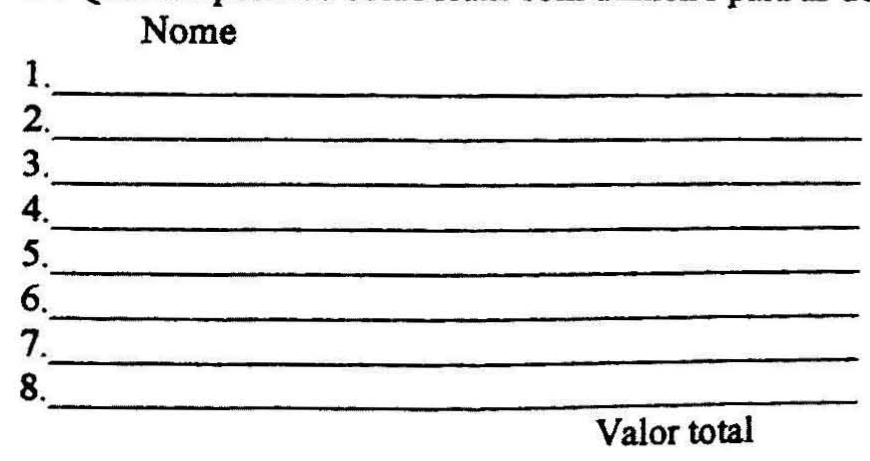

Valor

1.

2

5

6

8

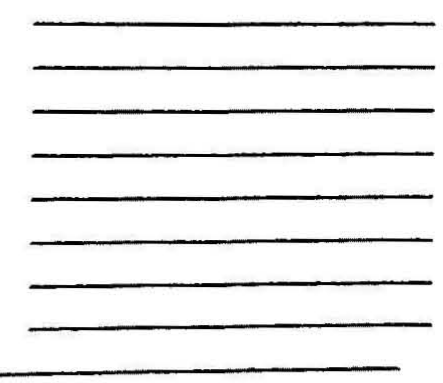

65 Que tipo de atividade desenvolve o seu companheiro?

66 Quantas pessoas moram habitualmente em sua casa? $\mathrm{N}^{\circ}$ de pessoas 
67 Qual o número de cômodos da casa que são utilizados pelas pessoas da família como dormitório? $\quad \mathrm{N}^{\circ}$ de cômodos

68 Qual é a sua escolaridade?

5 ( ) analfabeto

6 ( ) primário incompleto

7 ( ) primário completo

8 ( ) $1^{\circ}$ grau incompleto

9 ( ) $1^{\circ}$ grau completo

10 ( ) $2^{\circ} \mathrm{grau}$ incompleto

11 ( ) $2^{\circ}$ grau completo

12 ( ) superior incompleto

13 ( ) superior completo

99 ( ) NS/NR

69 DESCRITIVO DA HISTÓRIA OCUPACIONAL Empresa ou tipo de trabalho Datas Período (anos)

1.

2.

3.

4.

5.

6.

7.

8. 


\section{Anexo 5}

Procedimento para colheita tríplice do material cérvico-vaginal*SOUZA $\mathbf{R}$
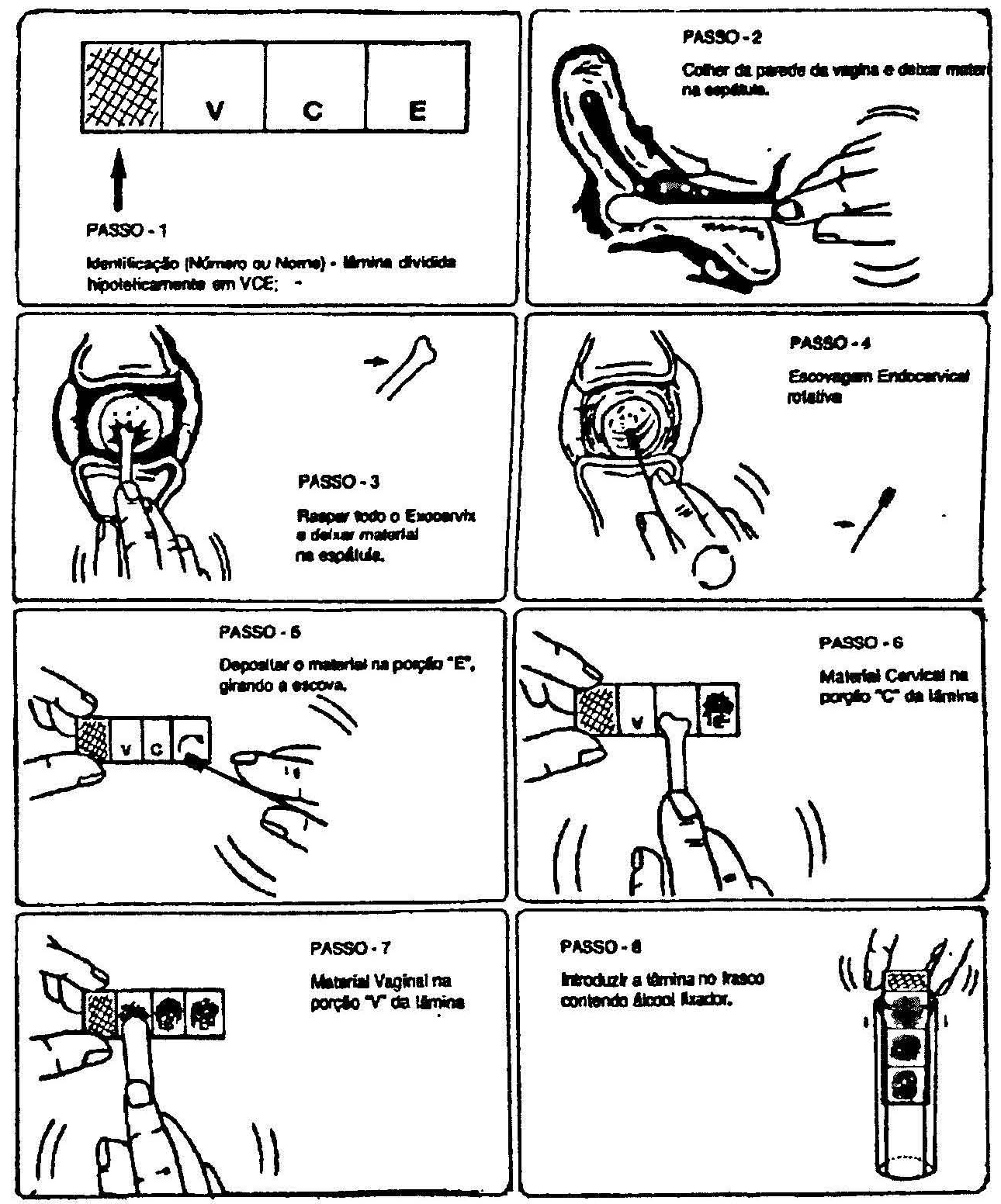

PASSO -

Itroctel a timina no kacos contendo stood lixador.

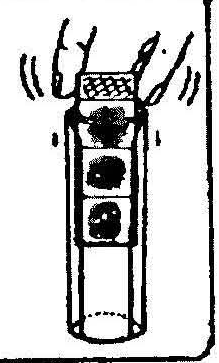




\section{Anexo 6}

\section{LAUDO DE COLPOCITOLOGIA}

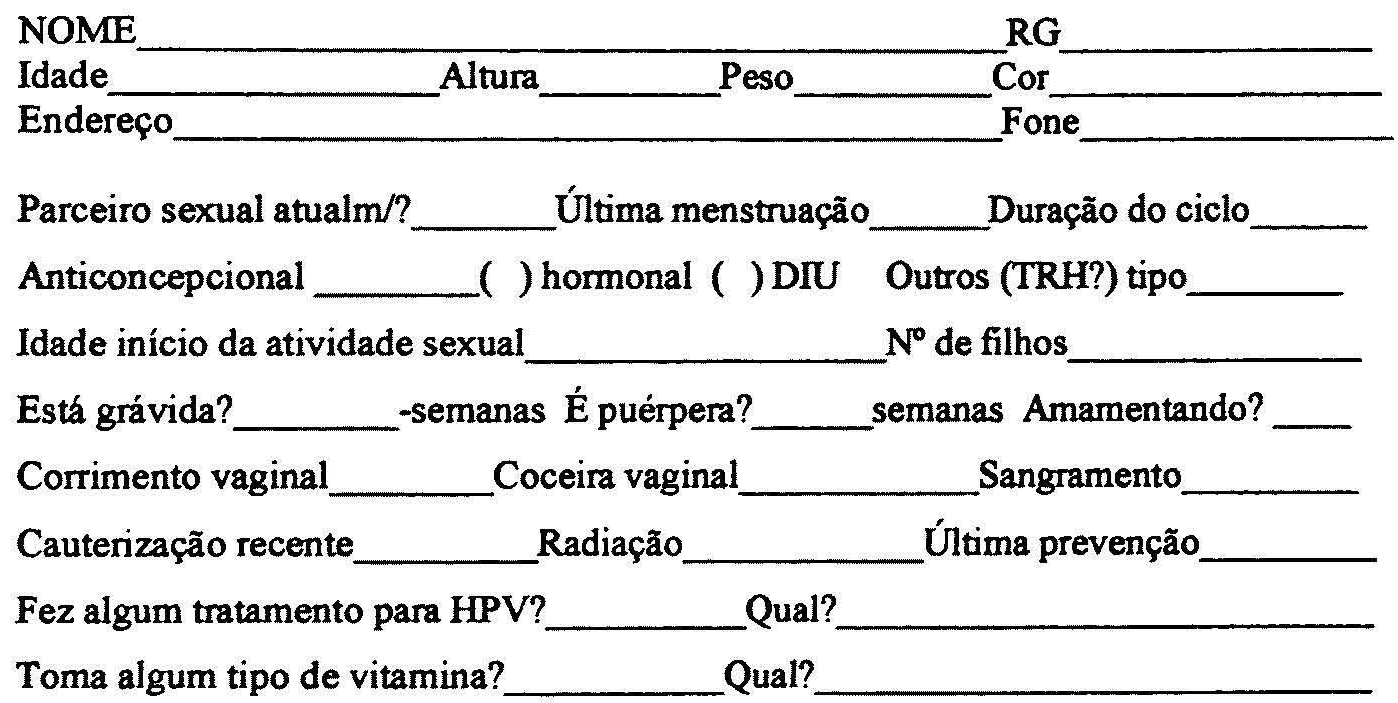

\section{RESULTADO}

Material colhido

Parede lateral - vagina ( ) Tipo de corrimento

Fundo do saco vaginal ( )

Tipo de lesão

Colo ( )

Endocérvix ( )

Schiller Negativo ( )

Sangrou d̀ coleta?

Schiller iodo claro ( )

Schiller Positivo( )

CITOLOGIA ANTERIOR classe (I) (II) (III) (IV) (V) 